\title{
ISTÁLLÓSKŐ REVISITED: THE OSSEOUS ARTEFACTS FROM THE LOWER LAYER
}

\author{
ANDRÁS MARKÓ \\ Hungarian National Museum \\ 14-16 Múzeum krt. Budapest, H-1088, Hungary \\ markoa@hnm.hu
}

\begin{abstract}
The Istállóskő cave is one of the classical Palaeolithic sites in Hungary, generally regarded as the only important Aurignacian locality in Hungary with two discrete culture bearing layers. The lower unit, characterised by the presence of split based points played a key role in several theories on the appearance of the Upper Palaeolithic in Europe, while in the upper layer some Mladeč or Olschewa type points were found.

In this paper the author reviews the antler and ivory artefacts found in the lower layer stored in the Hungarian National Museum. The reconstruction of assemblage formation was rather complicated, but the high number of fragments, the occurrence of typical macrofracture patterns and the rejuvenated implements shed light to the human behaviour. Finally a few pieces with sufficient preservation allow us to point some details to the operational chain of the osseous tool production.

All these aspects of the assemblage were determined by the topographic location of the cave, lying at a large relative height by the end of a long and deep valley, determining the nature of the human occupation of this locality. This raises the question of the comparability of the assemblages with other collections.
\end{abstract}

Keywords: Aurignacian, osseous tool, split based point, refitting, taphonomy

The Istállóskő cave lying in the Bükk Mountains, North-East Hungary was considered for a long time as the only important Aurignacian locality in Hungary. ${ }^{1}$ However, the recent analysis of the lithic artefacts showed that the typical forms of this Early Upper Palaeolithic entity are absent from each of the assemblage. The lower (former 'Aurignacian I') artefact bearing layer was excavated in the pale brown layer I (following the stratigraphic division by I. Vörös ${ }^{2}$ ) and dated to $>35-33 \mathrm{ka}$ according to the uncalibrated radiocarbon chronology. The lithic industry was compared to the assemblages from the Jankovich and the Bivak caves in Transdanubia (Hungary), the layer G1 of the Vindija cave in Croatia and to the collections from the open-air localities around Velky Šariš, Eastern Slovakia. The upper, 'Aurignacian II' layer, excavated in dark brown layer III is characterised by the co-occurrence of a typical blade industry and the Middle Palaeolithic and leaf shaped implements. This assemblage, associated with 31-28 ka old radiocarbon dates, was compared to the early Gravettian sites from where 'archaic' types were reported (e.g. Bodrogkeresztúr), to the supposed Gravettian assemblage of upper layer of the Szeleta cave (both in Northeastern Hungary), and to the Aurignacian-type industry of Bárca II (Eastern Slovakia). ${ }^{3}$

A recent paper reports the occurrence of a nosed and a shouldered end-scraper from the Aurignacian II assemblage excavated in 1950-1951. ${ }^{4}$ However, neither drawings nor photographs of these artefacts, claimed as having typological importance ${ }^{5}$ were published, so we can only renew our observations about the lack of these types

\footnotetext{
${ }^{1}$ VÉRTES 1955; VÉRTES 1956, 16-17; VÉRTES 1965, $164-$ 165; GÁBORI 1964, 9-11; 1969, 160; ALBRECHT et al. 1972; DoBOSI 1975; BÁNESZ 1976, 62-64; HAHN 1977, 121-123; SvoBODA-SimÁN 1989, 310-313; ADAMS 1998, 41-44; ADAMS 2007, 94; SiMÁN 2006; KoZŁOWSKI et al. 2009, 402-403.
}

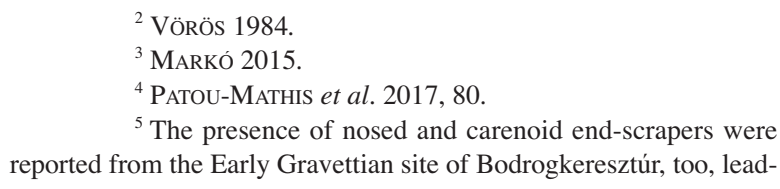

${ }^{5}$ The presence of nosed and carenoid end-scrapers were reported from the Early Gravettian site of Bodrogkeresztúr, too, lead- 
in each assemblage of the Istállóskő cave. ${ }^{6}$ On the other hand the backed bladelet excavated by Vértes in 1950 in the upper layer ${ }^{7}$ is neither mentioned nor listed by M. Patou-Mathis and her colleagues, and the majority of the osseous artefacts from the same entity (including a pendant, the typical Mladeč/Olschewa points, or a split based point - see infra) ${ }^{8}$ extensively discussed by L. Vértes, G. Albrecht and his colleagues, J. Hahn and V. Dobosi ${ }^{9}$ were also left out of consideration.

Moreover, during the excavations by L. Vértes a fragment of a typical leaf point was found in the upper layer and recently a half-made bifacial tool was also recognised in the same collection. ${ }^{10}$ In the paper by PatouMathis et al., however, three bifacial tools are listed ${ }^{11}$ but the drawings or photographs are absent again and no further references are given. Based on the presence of bifacial tools, the authors linked the assemblage only ambiguously to the Aurignacian industry. ${ }^{12}$

Concerning the lower artefact bearing layer of the Istálóskő cave it was claimed that "the Late Middle Palaeolithic Jankovichian cultural identity of the tool assemblage in LL, previously claimed (Markó 2015), cannot be supported here by the archaeological evidence" 13 which certainly reflects a misunderstanding as the term "Jankovichian' was used in my paper in a single footnote as "the poorly defined and problematic ... industry". ${ }^{14}$ In fact we suggested that in the assemblages of Jankovich, Bivak and Vindija caves, as well as the lower layer of the Istállóskö "at least the co-occurrence of 'Aurignacian'-type osseous tools on one hand and bifacially worked or Middle Palaeolithic lithics on the other is quite obvious". ${ }^{15}$

In the present paper my primary aim is to look through the antler and ivory artefacts of this 'Aurignacian I' layer excavated by L. Vértes ${ }^{16}$ and reviewed later several times ${ }^{17}$ from some previously not investigated points.

\section{FAUNAL REMAINS FROM THE LOWER LAYER}

The Istállóskő cave is the eponymous locality of the macromammal biostratigraphic stage dated to the Middle Würm (OIS 3) ${ }^{18}$ clearly dominated by the cave bear remains. ${ }^{19}$ Moreover, bones of further 10 herbivore and 14 carnivore mammal species, and several taxa of birds, amphibians and fishes were also collected in a lower number. The majority of the osseous artefacts are made of antler, probably of reindeer, however, in the faunal assemblage this species is represented only by wrist bones ${ }^{20}$ and only teeth and phalanxes of red deer were collected. ${ }^{21}$ On the

ing by V. T. Dobosi noting that '...the lithic industry of Bodrogkeresztúr-Henye with this 6 , not very typical carenoid end-scrapers is more "Aurignacian-like" than the stone tools of the real Aurignacian sites [i.e. the Peskő and the Istállóskő caves] in Hungary': DoBosI 2000, 27.

${ }^{6}$ Markó 2015, 30, and footnote 121 in the same paper. Otherwise, as the excavator stressed, the 'high scrapers' found in the upper layer are rather atypical pieces, without the characteristic secondary modification: VÉRTES 1955, 126.

${ }^{7}$ Vértes 1955, 125, Taf. XLV:5; HAhN 1977, 122, Taf. 147:4, MARKó 2015, 29, Fig. 6.5, Table 8. - Incidentally, characteristic Gravettian tools and cores were also found in the Istállóskő cave during the earlier excavations by Hillebrand, Saád and Vértes, for the details and the references see: MARKó 2015. - Since the publication of that paper I have had the opportunity to read the work of J. Hahn, suggesting a Gravettian affiliation to the upper layer of the Istállóskő cave, and another by V. Pohar about the role of backed pieces in the assemblage from the Potočka zijalka and generally in the Late Aurignacian: HAHN 1969, 82; POHAR 2004, 214-215.

${ }^{8}$ In their paper three not characteristic osseous artefacts are mentioned from the upper layer as having exact stratigraphic origin (PAtou-Mathis et al. 2017, 84-85). However, V. T. Dobosi gave the detailed provenance data of four ivory and nine antler artefacts, a pendant and the 'flute' from the same unit (DoBosi 2002).

${ }^{9}$ VÉRTES 1955; Albrecht et al. 1972; HAHN 1977; Dobosi 2002.
${ }^{10}$ MARKó 2015, 20, Fig. 6.3, 6.1. - In fact the stratigraphic position of the leaf point fragment is rather problematic, as it was found under a mushroom-shaped travertine formation at the wall of the cave and no detailed excavation diary is known from that day: MARKÓ 2015, 20.

${ }^{11}$ Patou-Mathis et al. 2017, Table 1. - Regrettably, all the data given by M. Patou-Mathis and her colleagues are unreliable.

${ }^{12}$ Patou-Mathis et al. 2017, 86.

${ }^{13}$ Patou-Mathis et al. 2017, 86.

${ }^{14}$ MARKó 2015, 28, fn 95. - Sharing Vértes' view, we may supposed that during the excavations of the Jankovich cave the material of several artefact-bearing layers could have been mixed. However the very weak field documentations suggest that the majority of the osseous tools was found in association with the Szeletian (sensu Prošek) leaf shaped points. For the details, see: MARKó 2013b, 23.

${ }^{15}$ MARKó 2015, 28

${ }^{16}$ VÉRTES 1955.

${ }^{17}$ Albrecht et al. 1972; HAHN 1977, 121-123; DoBOsI 2002.

${ }^{18}$ KRETZOI-VÉRTES 1965; VÖrÖS 1984; VÖRÖS 2000; VÖRÖs 2003-2004.

${ }^{19}$ During the last excavations over 18 thousand pieces of this species were registered, however, more than half of them were set aside during the field works: JÁNOSSY 1955, 149, 157; VöRÖs 2003 2004, 54-55.

${ }^{20}$ JÁNOSSY 1955, 160-161.

${ }^{21}$ JÁNOSSY 1955, 160. 
Table 1. Istállóskő cave: conjoinings of osseous artefacts

\begin{tabular}{|c|c|c|c|c|}
\hline $\begin{array}{l}\text { Number of } \\
\text { refit group }\end{array}$ & Inv. nr. & Place of recovery & Interpretation & \\
\hline \multirow[t]{2}{*}{ I } & $\mathrm{Pb} .50 / 1$ & & & \\
\hline & $\mathrm{Pb} .50 / 5$ & trench III, $-1.5-1.8 \mathrm{~m}$ & recent fracture & \\
\hline \multirow[t]{2}{*}{ II } & $\mathrm{Pb} .50 / 8$ & trench $\mathrm{V},-1.7-2.2 \mathrm{~m}$ & & Fig. 3.1 \\
\hline & $\mathrm{Pb} .50 / 49$ & trench VI, $-1.7-2.2 \mathrm{~m}$ & impact fracture? & \\
\hline \multirow[t]{2}{*}{ III } & $\mathrm{Pb} .50 / 13$ & trench III, $-2.0-2.5 \mathrm{~m}$ & & \\
\hline & $\mathrm{Pb} .50 / 53$ & trench III, $-1.8-2.4 \mathrm{~m}$ & snap fracture with weathered surface & \\
\hline \multirow[t]{3}{*}{ IV } & $\mathrm{Pb} .50 / 20$ & trench VI, $-1.7-2.2 \mathrm{~m}$ & & Fig. 1 \\
\hline & $\mathrm{Pb} .50 / 34$ & trench I, $-1.6 \mathrm{~m}$ & & \\
\hline & $\mathrm{Pb} .50 / 23$ & trench $\mathrm{V},-1.4-1.7 \mathrm{~m}$ & snap fracture with weathered surface & \\
\hline \multirow[t]{2}{*}{ V } & $\mathrm{Pb} .50 / 16$ & trench $\mathrm{V},-1.7-2.2 \mathrm{~m}$ & & Fig. 3.2 \\
\hline & $\mathrm{Pb} .50 / 22$ & trench III, $-1.5 \mathrm{~m}$ & impact fracture & \\
\hline \multirow[t]{2}{*}{$\mathrm{VI}$} & $\mathrm{Pb} .50 / 27$ & trench $\mathrm{V},-1,7-2,2 \mathrm{~m}$ & & Fig. 3.3 \\
\hline & $\mathrm{Pb} .50 / 173$ & & impact fracture? & \\
\hline \multirow[t]{2}{*}{ VII } & $\mathrm{Pb} .50 / 155$ & lower layer & & Fig. 2 \\
\hline & $\mathrm{Pb} .50 / 175$ & upper layer & simple fracture & \\
\hline \multirow[t]{2}{*}{ VIII } & $\mathrm{Pb} .50 / 99$ & trench III, $-1,5 \mathrm{~m}$ & & \\
\hline & $\mathrm{Pb} .51 / 19$ & trench IX, upper layer & snap fracture with weathered surface & \\
\hline
\end{tabular}

other hand bones and teeth of mammoth are absent from the excavated collection and this taxon is represented only by modified pieces of ivory ${ }^{22}$ suggesting that practically all the osseous artefacts were manufactured out of the cave. ${ }^{23}$ Importantly no sieving was practiced in 1950-1951, which may raise the possibility that little fragments of worked pieces including technologically important waste material (tongued pieces, microflakes etc.) were not recognised during manual selection in front of the cave. The high number of micromammal remains (e.g. 2490 bones and teeth of water vole Arvicola terrestris ${ }^{24}$ ), however, suggests that the recovery of little pieces and fragments was rather efficient.

\section{QUESTIONS AND METHODS}

The evaluation of the lithic artefacts from the Istállóskő cave proved obvious traces of post-sedimentation movement of the artefacts in the sediment sequence. ${ }^{25}$ After the review of the available literature the possible deformation of certain osseous tools, ${ }^{26}$ the differences observed in the state of preservation of single pieces ${ }^{27}$ and the supposed mixing of the sediment ${ }^{28}$ raised the necessity of systematic taphonomical investigations. The analysis of the successful refits (Table 1, Fig. 1-3) and the macroscopic and low-magnification microscopic observations ${ }^{29}$ on the degree of weathering, the traces of mechanical effects and the presence of black coating on the pieces made possible to trace some of the main points of the history of single artefacts.

On the other hand, during the analysis we focused on the description of the traces of manufacture and some morphological aspects of the tools. These observations may give some details about the blank production and the selection for tool-manufacture. During the data collection the concave, straight or convex longitudinal section of the artefacts proved to be informative. We assign the convex or concave longitudinal section of the pieces according to the nature of the exterior side, i.e. if this face is concave and the interior face with the spongy tissue of the antler is convex (Fig. 4), the piece is classified as 'concave'. In the case when the exterior side of the tool is convex and the interior side concave, the piece is sorted into the category of the 'convex tools'.

${ }^{22}$ JÁNOSSY 1955, 160; VÖRÖS 2003-2004, 68.

${ }^{23}$ Cf. Patou-Mathis et al. 2017, 85.

${ }^{24}$ JÁNOSSY 1955, 166.

${ }^{25}$ MARKó 2015, 29, 32

${ }^{26}$ VÉRTES $1955,114$.
${ }^{27}$ VéRTes 1955, Taf. XXXVI:3. A similar example from the upper layer was depicted on Taf. XLII:7 in the same article.

${ }^{28}$ E.g. presence of a split based point in the upper (Aurignacian II) layer: VÉRTES 1955, 124; c.f. DOBOSI 2002, 99

${ }^{29}$ The micro-photographs were made by a CETI Steddy-T 7300 trinocular and Nicon Coolpix 4200 camera. 
Besides, the bent or straight outline and the morphological axis of the pieces compared to the pattern of the spongy tissue of the antlers were also recorded.

Finally, in case of the points the study macrofracture patterns and the traces of reparation and rejuvenation of the tools are important questions of the Istállóskő osseous collections and allow drawing several behavioural conclusions.

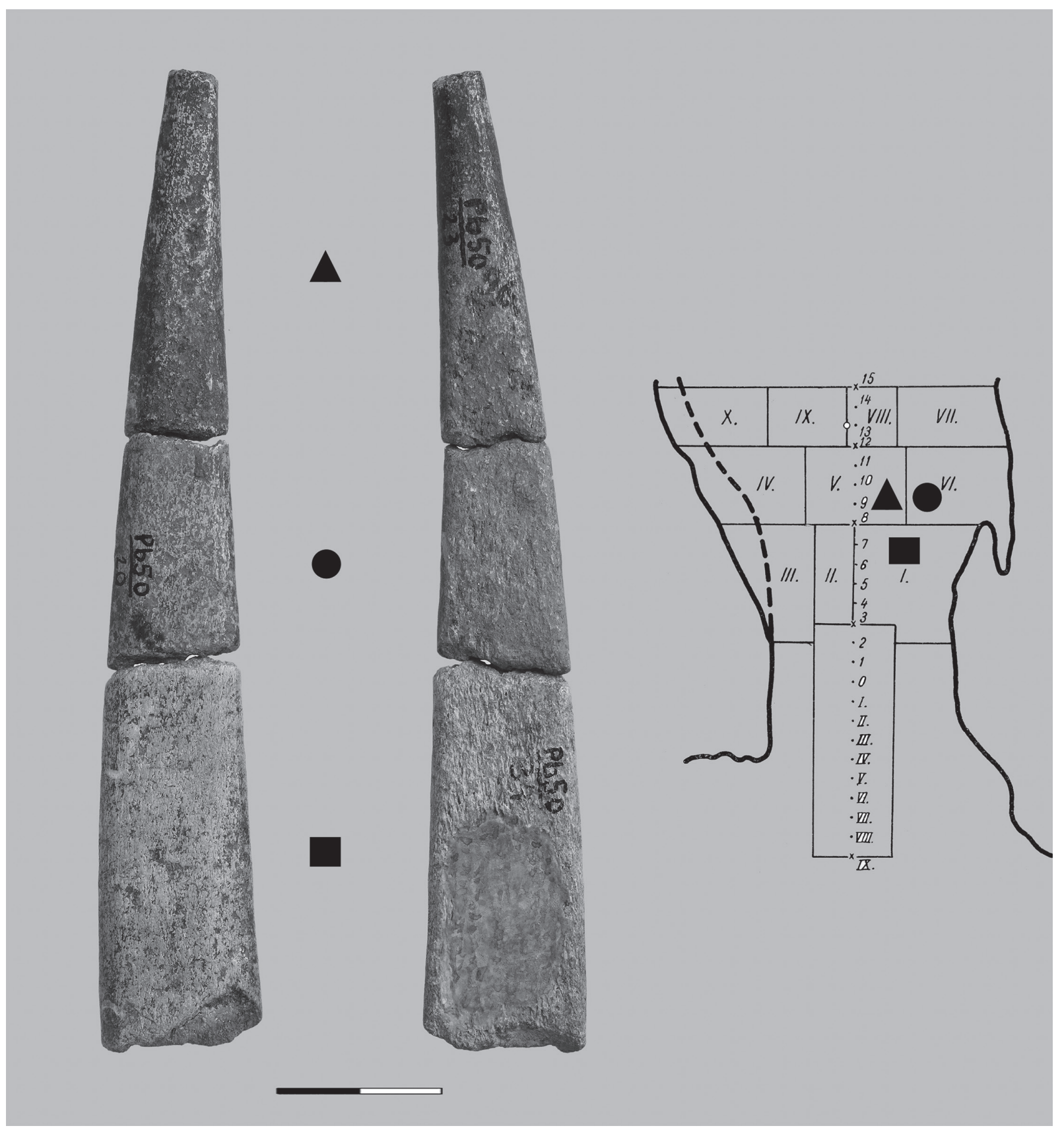

Fig. 1. Istállóskő cave, lower layer: refit group IV (photo: J. Kardos, Hungarian National Museum) 


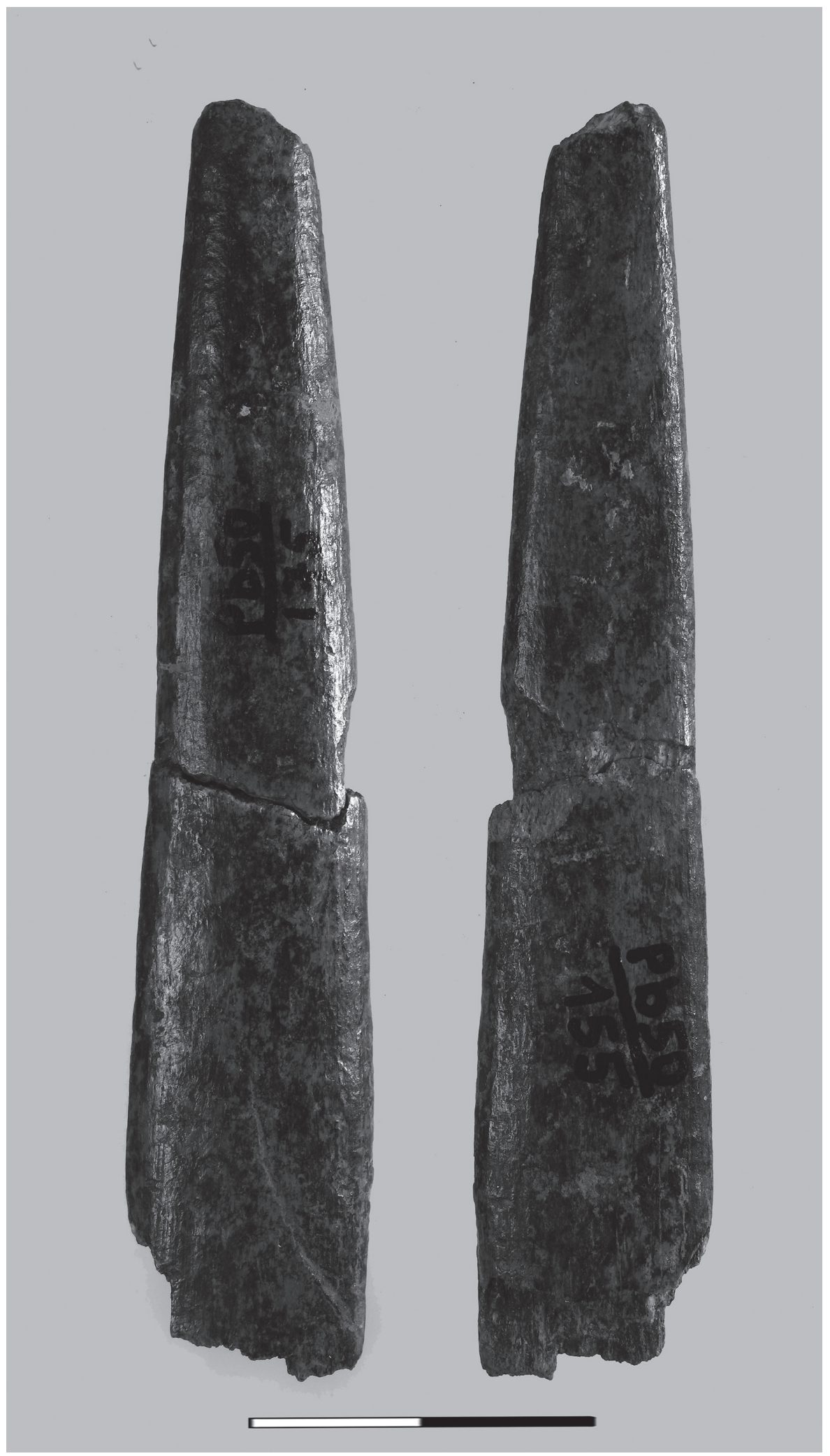

Fig. 2. Istállóskő cave, lower and upper layer: refit group VII (photo: J. Kardos, Hungarian National Museum) 


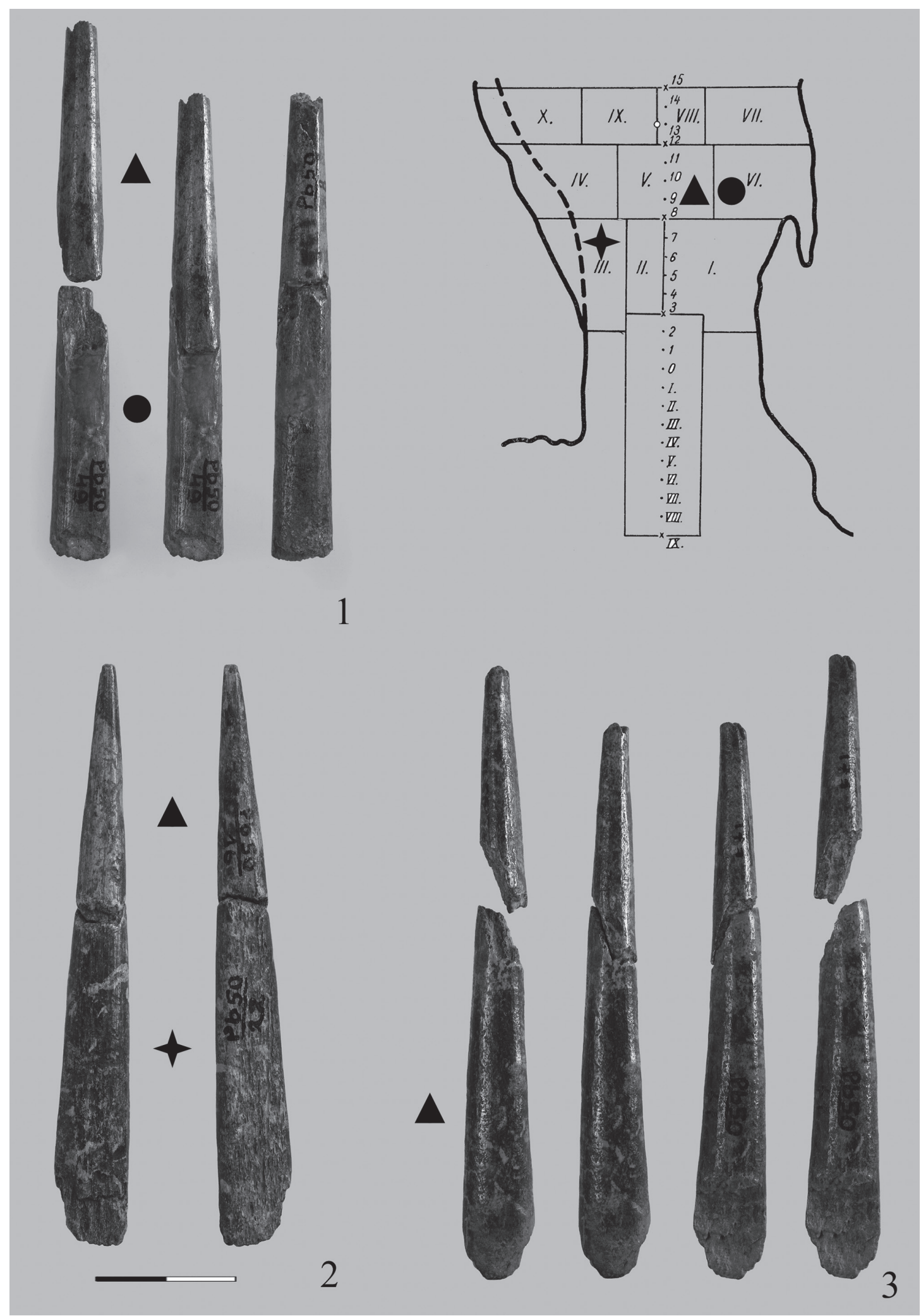

Fig. 3. Istállóskő cave, lower layer: refit group II (1), V (2) and VI (3) (photo: J. Kardos, Hungarian National Museum) 


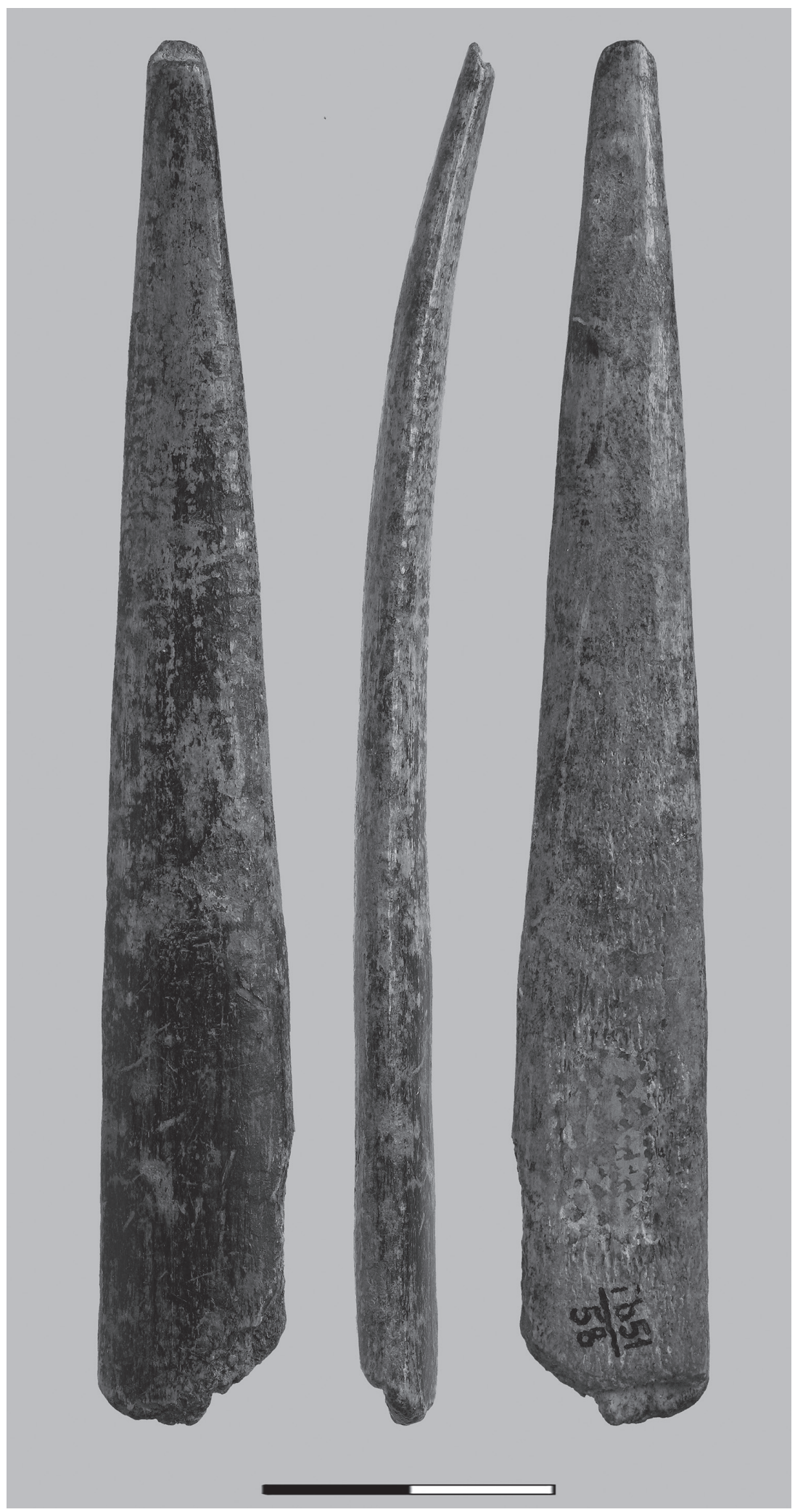

Fig. 4. Istállóskő cave: split based point with concave profile 


\section{SPATIAL DISTRIBUTION OF THE OSSEOUS INDUSTRY OF THE LOWER LAYER OF THE ISTÁLLÓSKŐ CAVE}

The assemblage studied in this paper was first recognised and excavated by L. Vértes in 1950-1951. As a total of 80 pieces of antler and at least 53 ivory artefacts were collected from the pale brown layer, identified as belonging to the 'Aurignacian I' culture (Table 2). According to the available data trench III lying in the northern side of the entrance section was the richest of the excavations in the cave (with 17 pieces of antler and several ivory artefacts). Most of the pieces were collected from the uppermost level of the lower artefact-bearing layer, from the depth of 1.5-1.8 meter, ${ }^{30}$ however, four antler tools and an ivory stick was found in a considerably deeper level. Another dense concentration of osseous artefacts was documented at the southern wall of the cave in trench VI.

\section{TAPHONOMICAL OBSERVATIONS}

Aside from the recent injuries happened during or after the excavations ${ }^{31}$ (e.g. breaks of refit group I) or the drillings of the radiocarbon sampling (Fig. 1; Fig. 3.1; Fig. 7) a number of traces of natural effects can be clearly registered on the artefacts. The majority of the pieces are glued from several fragments, mainly of simple (snap) breaks with rather weathered surfaces. In some cases it was possible to conjoin even if not perfectly some further pieces (refit groups III, IV from the lower and group VIII from the upper layer). The elements of refit group IV (Fig. 1) were collected from three trenches, which may prove the horizontal 'movement' of the artefacts after the fragmentation, illustrating the epigenetic taphonomical events. ${ }^{32}$ Refit group VII (Fig. 2) on the other hand, clearly documents the direct connections between the lower and the upper artefact bearing layers. ${ }^{33}$

Localised traces of chemical effect (weathering) or mechanical impact (blows) were observed on the surface of 14 antler and 4 ivory artefacts (e.g. on the distal fragment of refit group IV: Fig. 1), in the case of the antler artefacts typically on the exterior (or convex) part of the tools. In four cases rather irregular transversal scratches, similar to the retoucheurs reported from different assemblages were observed on the same part of the artefacts (Fig. 5). However, the light weight and small thickness of Istállóskő specimens question the cultural origin of the observed phenomenon, suggesting the role of natural mechanical agents (e.g. sediment movement) in the formation of these traces.

Both transversal scratches and traces of weathering are generally covered by dark brown or black coating which makes difficult or even impossible the clear observation of the surface of the artefacts. The presence of darkcoloured film generally linked to the formation of manganese oxide (birnessite in mineralogical point of view) or calcium phosphate (hydroxyl-apatite) $)^{34}$ is a common feature on the pieces imbedded in cave deposits. Interestingly, this coating was rarely documented on the spongy tissue (interior face) of the antler tools (Fig. 5) and never on the lithic artefacts from the Istállóskő cave. Moreover, the ivory pieces with plano-convex or biplan cross section show a different pattern as no coating was observed on the lateral part of the pieces. Finally the surface of the ivory stick of circular cross-section excavated in the lowermost level of trench III is covered with black coating, with the exception of two narrow bands of 'fresh' yellowish colour, running longitudinally on the opposite parts of the tool (Fig. 14).

Further questions are raised by the observation that at the perforation of the ivory pendant the black coating is missing and the characteristic traces of manufacture (scraping) is clearly visible (Fig. 12.2). Finally on the

${ }^{30}$ Importantly, in this level artefacts of the upper layer were also found: MARKÓ 2015, 20, note 56. The recent refit studies confirmed my earlier conclusions as the artefact fragments found at the depth of 1.5 $\mathrm{m}$ in this trench were partly conjoined to a fragment found in the lower layer (group V) partly to a piece of the upper one (refit group VIII).

${ }^{31}$ The vandals ("human beasts" mentioned by Vértes in his popular book or "soldiers" in the excavation diary) destroyed the profiles of trench III on 5 June 1950. In the next day more than one hundred of ivory fragments were collected from the debris material of at least one cubic meter.

${ }^{32}$ KoleSNIK 2003.

${ }^{33}$ U. Albarella suggested to use the term 're-deposition' when the bones or osseous artefacts were found in a younger layer than they were originally buried and 'intrusion' when they were col- lected from earlier layer. In the cases when the original and the excavated stratigraphic position belong to different phases the terms 'residuality' and 'contamination' are suggested (ALBARELla 2016). The fragments of the piece found in two cultural layers clearly belong to one of these later categories, however it is seemingly impossible to decide if one of the fragments was moving downward or the other piece moved upward from the layer of the initial burial. On the other hand the identical colour and the preservation of the pieces suggest that the taphonomical event is clearly of postgenetic origin, i.e. placed well after the primary deposition.

${ }^{34}$ White et al. 2009; ONAC 1996, 111. - Concerning the Istállóskö bones the presence of iron and magnesium oxide was suggested by PATOU-MATHIs et al. 2017, 83. 
Table 2. Istállóskő cave: distribution of the osseous artefacts in the lower ('Aurignacian I') layer

\begin{tabular}{|c|c|c|c|c|c|c|c|c|c|c|c|c|}
\hline \multirow[b]{2}{*}{ Trench } & \multirow[b]{2}{*}{ Depth } & \multicolumn{6}{|c|}{ Antler } & \multicolumn{4}{|c|}{ Ivory } & \multirow[t]{2}{*}{ Total } \\
\hline & & $\begin{array}{l}\text { Arte- } \\
\text { facts }\end{array}$ & Blank & $\begin{array}{c}\text { Rough- } \\
\text { out }\end{array}$ & SBP & $\begin{array}{c}\text { Bevelled } \\
\text { point }\end{array}$ & Pendant & Artefacts & Rod & Stick & Pendant & \\
\hline \multirow[t]{3}{*}{ I } & $-1.6 \mathrm{~m}$ & 1 & & & & & & & & & & 1 \\
\hline & $-1.9 \mathrm{~m}$ & 1 & & & 1 & & & & & & & 1 \\
\hline & $-2.0-2.4 \mathrm{~m}$ & 1 & & & & 1 & & & & & & 1 \\
\hline II & $-1.8-1.9 \mathrm{~m}$ & 1 & & & & & & 1 & 1 & & & 2 \\
\hline \multirow[t]{6}{*}{ III } & $-1.5 \mathrm{~m}$ & 1 & & & & & & & & & & 1 \\
\hline & $-1.5-1.8 \mathrm{~m}$ & 7 & & & 2 & & & 1 & 1 & & & 8 \\
\hline & $-1.8 \mathrm{~m}$ & 1 & & & 1 & & & 4 & 4 & & & 5 \\
\hline & $-1.8-2.4 \mathrm{~m}$ & 1 & & & 1 & & & & & & & 1 \\
\hline & $-1.5-2.0 \mathrm{~m}$ & 3 & & & 1 & 1 & & & & & & 3 \\
\hline & $-2.0-2.5 \mathrm{~m}$ & 4 & & & & & & 1 & & 1 & & 5 \\
\hline IV & lower layer & 3 & & & 2 & & & & & & & 3 \\
\hline \multirow[t]{2}{*}{$\mathrm{V}$} & $-1.4-1.7 \mathrm{~m}$ & 3 & & & 2 & & & & & & & 3 \\
\hline & $-1.7-2.2 \mathrm{~m}$ & 3 & & & & 2 & & & & & & 3 \\
\hline \multirow[t]{4}{*}{ VI } & $-1.1-1.4 \mathrm{~m}$ & 4 & & & 1 & 1 & & $>37$ & 1 & & & $>41$ \\
\hline & $-1.4-1.7 \mathrm{~m}$ & 3 & & & & 1 & & 1 & & & & 4 \\
\hline & $-1.7 \mathrm{~m}$ & 1 & & & & & & & & & & 1 \\
\hline & $-1.7-2.2 \mathrm{~m}$ & 5 & & & 3 & & & & & & & 5 \\
\hline VII & lower layer & 4 & & & & & & & & & & 4 \\
\hline \multirow[t]{2}{*}{ VIII } & upper/lower layer & 2 & & 1 & & & & & & & & 2 \\
\hline & lower layer & 4 & & & 2 & & & 1 & & & 1 & 5 \\
\hline IX & lower layer & 1 & & & & & 1 & & & & & 1 \\
\hline$X$ & lower layer & 1 & & & & & & & & & & 1 \\
\hline Total & & 55 & & 1 & 16 & 6 & 1 & $>46$ & 7 & 1 & 1 & $>101$ \\
\hline unknown & & 25 & 1 & & 7 & 3 & & 7 & 3 & & & 32 \\
\hline Total & & 80 & 1 & 1 & 23 & 9 & 1 & $>53$ & 10 & 1 & 1 & $>133$ \\
\hline
\end{tabular}

surface of at least four antler artefacts (Fig. 3.2; Fig. 5) a thin, irregularly running yellowish ('fresh') band, similar to the root impressions are documented, but without any traces of chemical alteration. These observations raised the necessity of the future investigations about the taphonomical importance of the dark coating on the artefacts.

In the following the complexity of the site formation is illustrated by some characteristic examples. The first antler point was refitted from three fragments shortly after the excavations ${ }^{35}$ (Fig. 5). Regrettably the details of the recovery of the pieces are unknown, however, the proximal part of the piece showing transversal scratches is more intensively weathered than the medial and distal fragment of the same piece. The traces of manufacture are clearly visible on the distal part, while the proximal one is covered by dark film with the exception of the irregular light band mentioned above. The transversal scratches were formed obviously after the fragmentation of the artefact but before the precipitation of the black coating found only on the exterior side of the artefact denoting the complicated taphonomical history of this artefact.

Similarly, clear differences of the weathering degree are documented in case of the elements of refit groups IV (Fig. 1) and V (Fig. 3.2), too. Generally speaking the recent observations strengthened our conclusions based on the refit studies of lithic implements ${ }^{36}$ that the site formation was a rather complicated process in the Istállóskó cave, which could be reconstructed only in minute part after several decades of the field works. Importantly very similar differences in the preservation of the fragments of the same artefact can be recognised on an artefact excavated by Fr. Prošek in the Dzeravá skála (Little Carpathians, Western Slovakia). ${ }^{37}$ In both cases, however, the rather scarce field observations and the very low number and density of the artefacts do not allow us to draw far-reaching conclusions about the important questions of the site formation.

\footnotetext{
${ }^{35}$ VÉRTES 1955, Taf. XXXVI:3.

${ }^{36}$ Refit group 4 and 5, see: MARKó 2015, 9, Fig 1.
}

\footnotetext{
${ }^{37}$ KAMINSKÁ 2014, Obr 77.20.
} 


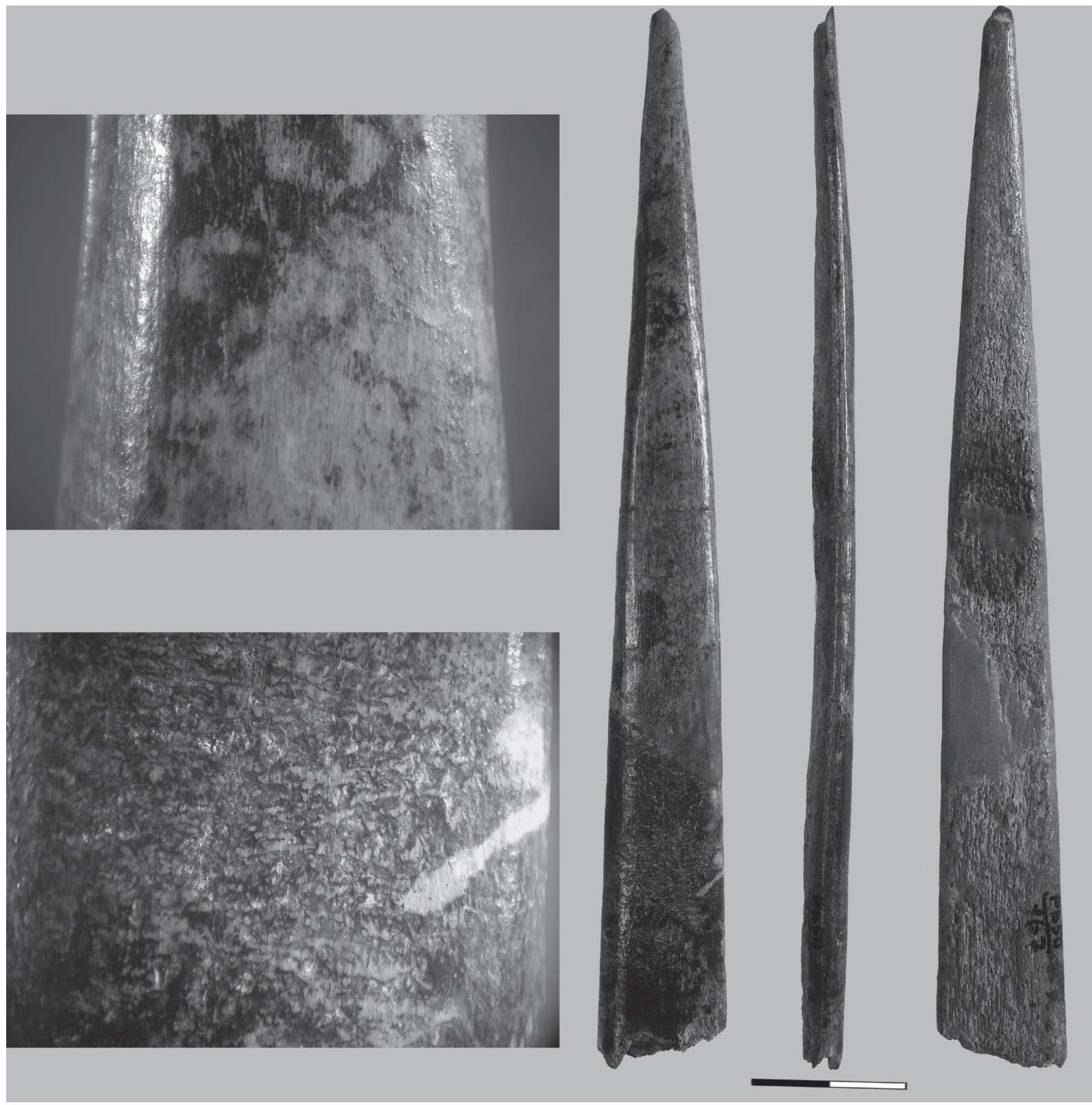

Fig. 5. Refitted fragments of different preservation (photo: J. Kardos, Hungarian National Museum)

\section{ARTEFACTS OF ANTLER IN THE LOWER LAYER OF THE ISTÁLLÓSKŐ CAVE}

During excavations of the lower culture layer no unmodified antler was found. The morphology of the single blank (Fig. 6) with a right and an oblique running lateral side (breakage plane), largely corresponds to the pieces produced during the modern experiments. ${ }^{38}$ No traces of surface manufacture are visible on the Istállóskő artefact, however, the clear shine and the longitudinal striations documented on both faces of the distal part and the less clear crushing on the proximal part shows that this item was possibly used as an intermediate piece. ${ }^{39}$ The measured angle of the active part is $34^{\circ}$, which is more obtuse than optimal angle experi-

\footnotetext{
${ }^{38}$ TEJERO et al. 2012.
}

${ }^{39}$ TARTAR 2003; TEJERO et al. 2012, 340-342. 


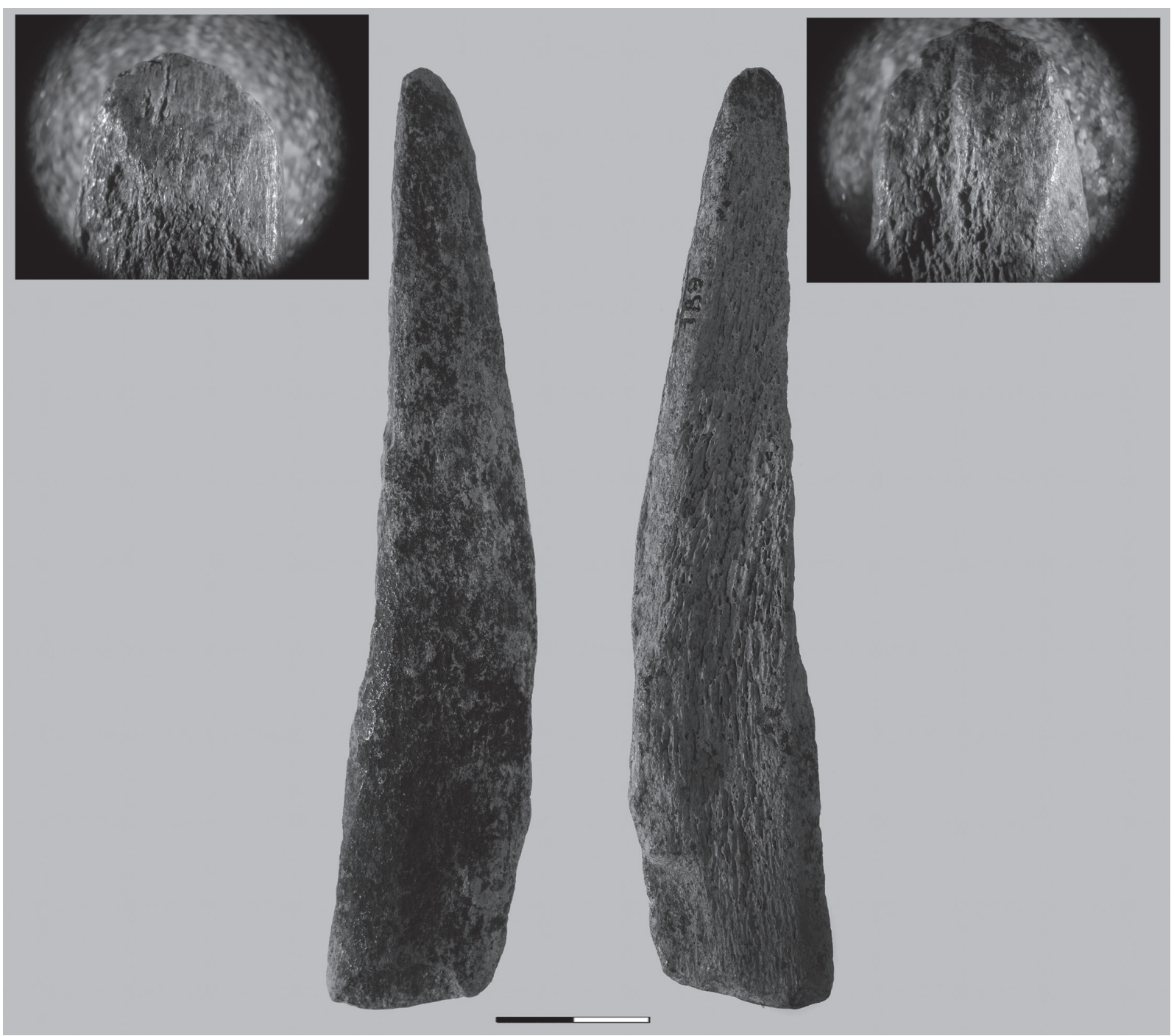

Fig. 6. Antler blank with traces of use as an intermediate tool (photo: J. Kardos, Hungarian National Museum)

enced during the production of points of red deer antler. ${ }^{40}$ In our view the piece was probably used for manufacturing of the ivory (cf. infra).

The single rough-out of antler (Fig. 7) with convex longitudinal section was found in trench VIII. Importantly in the hand-written field documentation originally layer III (i.e. the dark brown, 'Aurignacian II' layer) was given as the place of recovery of this piece, modified several days later to the lower, pale brown layer I. ${ }^{41}$ At the base of the tool on the interior side a groove probably left by a pointed intermediate piece (tip of an antler?) used during the blank production is observed. On the lateral and exterior faces traces of longitudinal scraping, the first steps of the tool production are observed.

Finally, on the lateral parts of an artefact (Fig. 8) clear traces of manufacture (convex lines of scraping) with step-like termination can be detected, while the exterior and the interior surfaces were not modified. The proximal part of this piece reminds us to the split based points and originally we interpreted the artefact as a roughout, even if the morphology of the piece suggests a rather different way of manufacture and waste material than the 


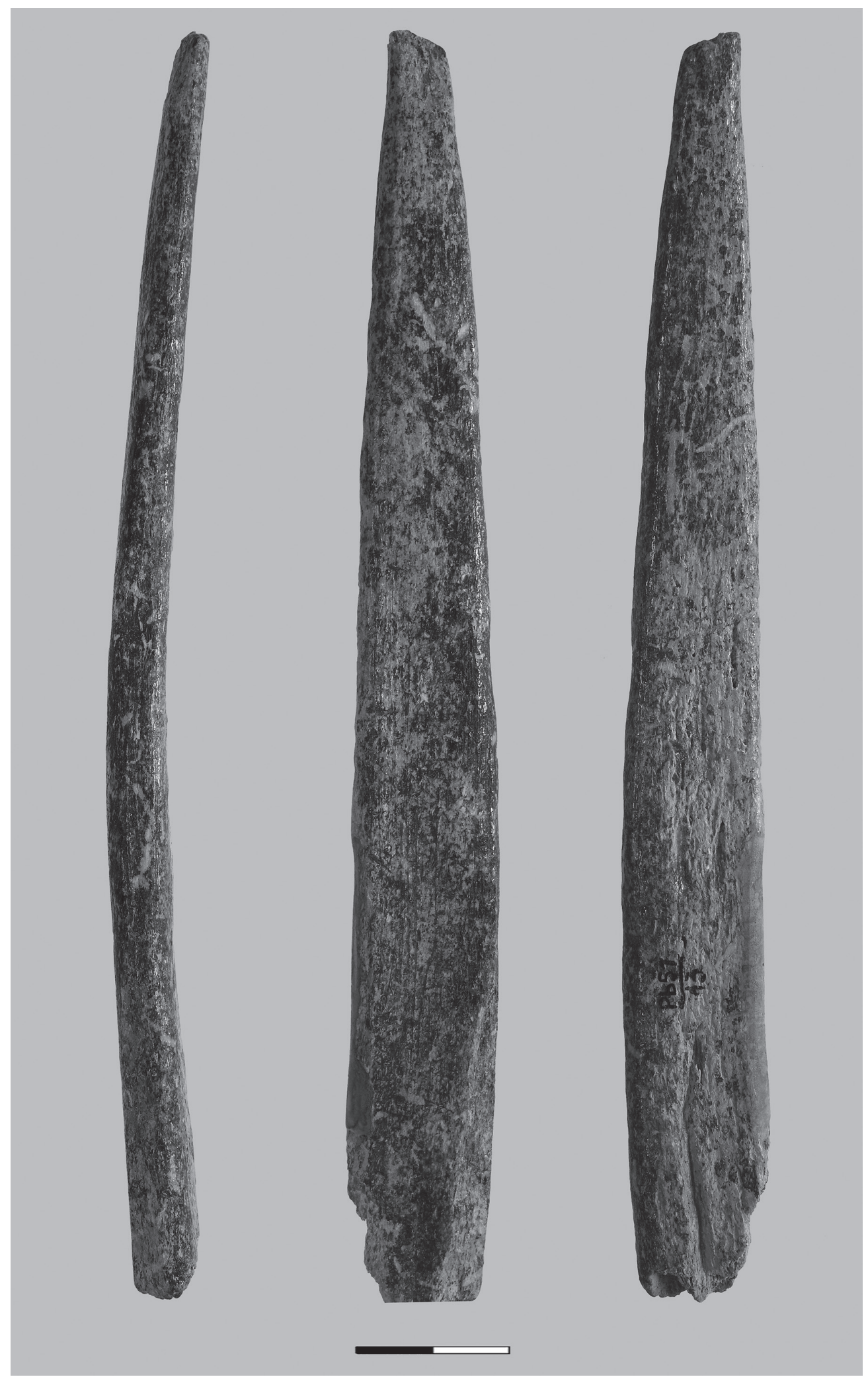

Fig. 7. Rough-out of antler from the Istállóskő cave (photo: J. Kardos, Hungarian National Museum) 


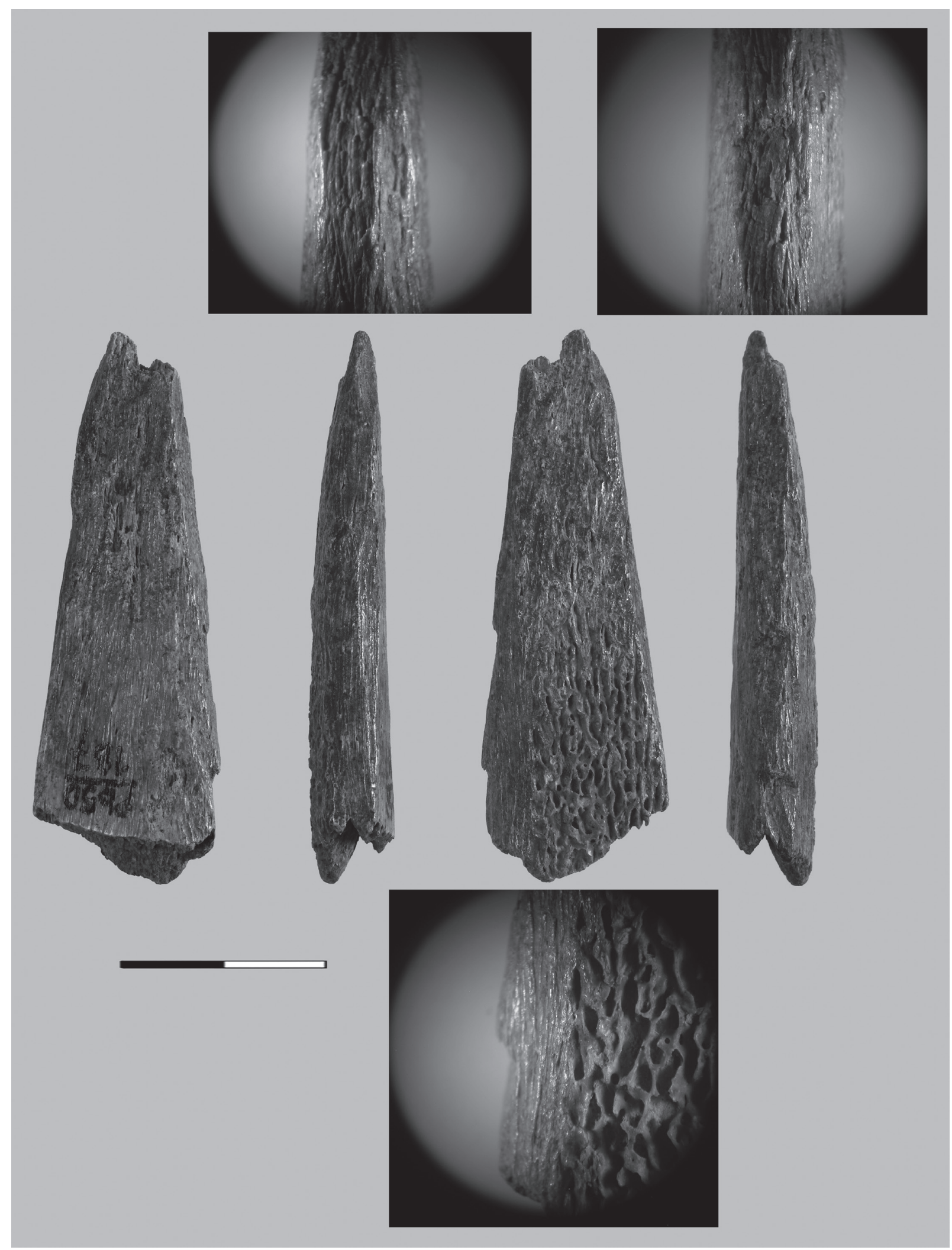

Fig. 8. Waste material from the manufacturing of an antler tool from the Istállóskő cave (photo: J. Kardos, Hungarian National Museum) 
experiments proved. ${ }^{42}$ Most probably this piece was a waste form of the blank segmentation, in some aspects similar to the pattern of «en diabolo», ${ }^{43}$ but the intense thinning is restricted to the lateral parts and it was not processed on the whole periphery of the artefact. Unfortunately, no clear data are known about the recovery of this piece, unique in the assemblage of the lower layer of the Istállóskő cave.

\section{Split based points}

In the studied collection as a total of 23 split based points are found, all made of antler, most probably of reindeer. At three artefacts both wings are broken and the artificial nature of splitting is rather questionable. At six pieces one of the wings was slightly injured and on six other ones this wing was broken; only eight tools have an intact base. Interestingly enough there are three pieces in the assemblage of which the splitting, most probably of natural origin is found on the distal part of the artefact (Fig. 3.1).

The provenance data of 16 split based points are known on the level of trenches and at relative depth (Table 2). According to the documentations five points were collected in trench III (the depth is varying from 1.5 to $2.4 \mathrm{~m}$ ) and four tools in two spits of trench VI, finally, two split based points were found in every one of trenches IV, V and VIII.

About the blank selection only indirect data are available: three pieces are of convex and one is of concave in longitudinal section (Fig. 4). L. Vértes ${ }^{44}$ supposed that the sediment pressure led to the deformation of one of the points. Although three of the four pieces were found in different spits of trench III artefacts including split based points with straight profile were also found in the same part of the cave suggesting that instead of taphonomical explanation ecological arguments (e.g. the scarcity or poor quality of the antler raw material forced humans to utilise the curved part of the beam) or intentional human selection may also be taken into consideration.

The distribution of the cross-section among the split-based points is listed in Table 3. Seemingly the ideal points had most probably plano-convex or biconvex section at the proximal part and oval-shaped section at their distal part, while the pieces of plano-convex or oval cross-sections are fragmented pieces. In 13 cases traces of spongy tissue are visible on the interior side of the artefact, generally missing from the supposed distal fragments.

Because of the fragmentation and the black coating relatively few data are available about the preparation of the proximal part of the tool. At six pieces, however, one of the sides was facetted, i.e. prepared by longitudinal scraping. Because of the fragmentary state of the artefacts and the lack of waste material very few data are available about the manufacture of the basal split. In a single case, however, the "type C modification", ${ }^{45}$ most probably the failed splitting can be supposed. The basal part of the split base point found in the Szeleta cave, as well as the nonsplit base point excavated in the Jankovich cave was prepared by scraping on both sides of the tool ${ }^{46}$ from the Istállóskő assemblage, at the same time, there is no data of the use of this way of base manufacturing.

Bending fracture was observed on four split-based points. Although the fracture surface is generally weathered, in one case it was possible to refit the tip to the proximal fragment of the tool (refit group III), both found in

Table 3. Cross section of the split based points from the lower layer of the cave

\begin{tabular}{|l|l|l|}
\hline cross-section & pieces & presence of spongy tissue \\
\hline rectangular & 2 & 2 \\
\hline plano-convex & 6 & 4 \\
\hline biconvex & 5 & 2 \\
\hline oval & 6 & 2 \\
\hline plano-convex + oval & 2 & 2 \\
\hline biconvex + oval & 2 & 1 \\
\hline
\end{tabular}

\footnotetext{
${ }^{42}$ TEJERO et al. 2012.

${ }^{43}$ Rigaud 1972; Le Dosseur 2003. - c.f. TEJERo 2014, 81.

${ }^{44}$ VÉRTES 1955, 114; Taf. XXXIV-XXXV:15.
}

\footnotetext{
45 TARTAR-White 2013, 2736-2737.

${ }^{46}$ MARKó 2013a, Fig. 8.

${ }^{47}$ c.f. TeJero 2014; TeJero-Grimaldi 2015, 62.
} 
trench III and roughly in the same stratigraphic position. On the other hand elements of refit group II and V (Fig. 3.1,2) were excavated in two neighbouring trenches.

Classifying the osseous artefacts found in the lower layer of the Istállóskő cave the main problem is the high number of broken pieces. It is virtually impossible to recognise the characteristic split based points in cases of medial or distal fragments. ${ }^{47}$ Typically, refit groups II and VI (Fig. 3.1,3) represent the reconstruction of a characteristic breaking pattern, with a point of circular or oval cross-section and segment-like fracture pattern, identified earlier as awls ${ }^{48}$ in one hand and a piece with spoon-shaped distal fragment, similar to the "chisel" of the collections in the other one. ${ }^{49}$ As a total four proximal ("chisel") and four distal fragments ("awl"), all having typical fracture surfaces, were identified in the collection. I suppose that in these cases we are faced with impact fractures but the details should be clarified by specialised experimental investigations. ${ }^{50}$

Several pieces of the assemblage were fragmented according to a pattern similar to the burins. On the other hand, at three artefacts found in trench III and IV important asymmetry of the outline of the tool was observed. As the recent experiments suggest the final shaping of the medial and distal part of the tool, including the tip ${ }^{51}$ was carried out only after splitting the base of the tool, I suppose that these pieces from the Istállóskő cave show rather the rejuvenation of the distal part of the artefacts, fractured according to this pattern. The artefact on Figure 9.1 is in fact a characteristic fragment of this pattern of which the left side is the breakage surface.

Finally, in one case the tip of a split based point was rejuvenated by scraping on both faces of the tool (Fig 10.1). Importantly at the distal part of another piece having concave longitudinal section and damaged base typical bifacial spin-off fracture is observed, suggesting that the rejuvenated piece was most probably damaged in the same way. Moreover, the diagnostic bifacial spin-off fracture may also be observed on tool with concave section, generally regarded as not optimal for the projectile points. Finally, the basal part of the rejuvenated point is seemingly intact, suggesting that this extremity was also repaired after the aggressive shock leading to the impact fracture. On the other hand, the very small split based points from the Istállóskő cave (Fig. 9.2,3), earlier interpreted as arrowheads ${ }^{52}$ are probably results of repeated rejuvenation of the artefacts.

\section{Non-split based tools of antler}

The intuitive category of the "shouldered points" of L. Vértes, ${ }^{53}$ i.e. the bevelled points (Fig. 11), is represented by nine specimens in the collection. Interestingly, only a single piece was collected in the artefact-rich trench III. The similar artefacts collected in the nearby Szeleta cave (Bükk Mountains, Northern Hungary) or in the Protoaurignacian layer of the Fumane Rockshelter (Italy) ${ }^{54}$ were interpreted as probable split based points. In other collections the pieces with identical breakage pattern were classified as not finished tools due to the failure of tool manufacturing..$^{55}$ The Istállóskő specimens, however, are seemingly ready-made pieces with perfectly shaped exterior surface and carefully elaborated tip. These unusually large artefacts seem to form a closed morphological group in the collection with intentionally shaped and not fragmented base.

Several fragments including elements of refit group IV (Fig. 1) with a biplan cross-section clearly differ from the split based points. Although these flat and broad pieces form a characteristic group again, their fragmentary state makes difficult to sort them into a well-defined category. However the artefacts are similar to the tools from the Mokriška jama (Slovenia), ${ }^{56}$ moreover, similar pieces were reported from the Vindija cave and the Velika Pećina (both in Croatia), ${ }^{57}$ too.

Finally, among the antler tools of the Jankovich cave several medial fragments with sub-rectangular cross section $^{58}$ are clearly different from the above mentioned artefact classes. In the collection of the Istállóskő cave a 1977,122

${ }^{48}$ VÉrTes $1955,118-119$, Taf. XXXVIII:8,12-15; HAHN

${ }^{49}$ VÉRTES 1955, 1965; HAHN 1977, 122; DoBOSI 2002, 88.

${ }^{50}$ In the monograph of the Potočka zijalka artefacts with similar fracture pattern were published from layer 5 (BRODARBRODAR 1983, T 11.27) and from not specified part of the cave sediment (BRODAR-BRODAR 1983, T 20.24,25, T 21.23).

${ }^{51}$ TARTAR-WHITE 2013, 2736.

\footnotetext{
52 VÉRTES 1955, 115-116.

${ }^{53}$ VÉRTES $1955,117-118$.

${ }^{54}$ Bertola et al. 2013, 142, Fig. 17.1

55 TARTAR-White 2013, 2740, Fig. 18

${ }^{56}$ BRODAR 1985

${ }^{57}$ KARAVANIĆ 2016, 50.

${ }^{58}$ MARKÓ 2011; 2013
} 


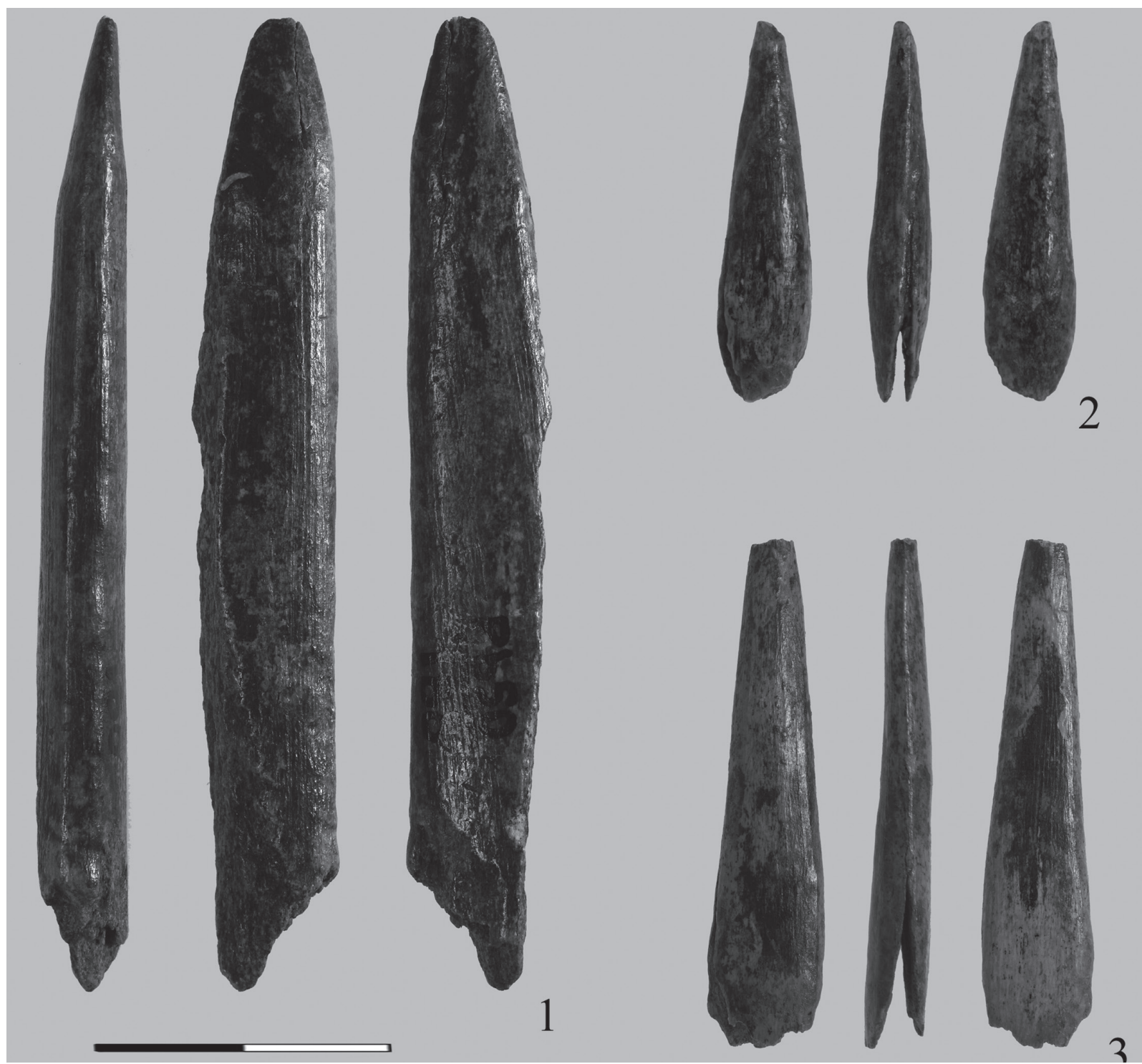

Fig. 9. Fragment of a tool (1) and littl split based points (2-3. photo: J. Kardos, Hungarian National Museum)

single medial fragment is found with well visible traces of longitudinally scraping. The slightly convergent lateral sides suggest that if this pieces was a pointed artefact it minimal length must have been longer than $15 \mathrm{~cm}$.

\section{Pendant of antler}

During the excavations of the lower layer in trench IX a pendant of antler (Fig. 12) was found. On the interior face of the piece of irregular pentagonal shape the presence of spongy tissue is clearly visible. The base of the artefact was manufactured by two, the medial and distal part by one and one asymmetrical cut. The drilling of the hole was started from both faces of the piece, similarly to the biconical drilling of a steatite pendant published e.g. from the Bombrini Rockshelter. ${ }^{59}$

${ }^{59}$ BERTOLA et al. 2013, 132, Fig. 8.6. 


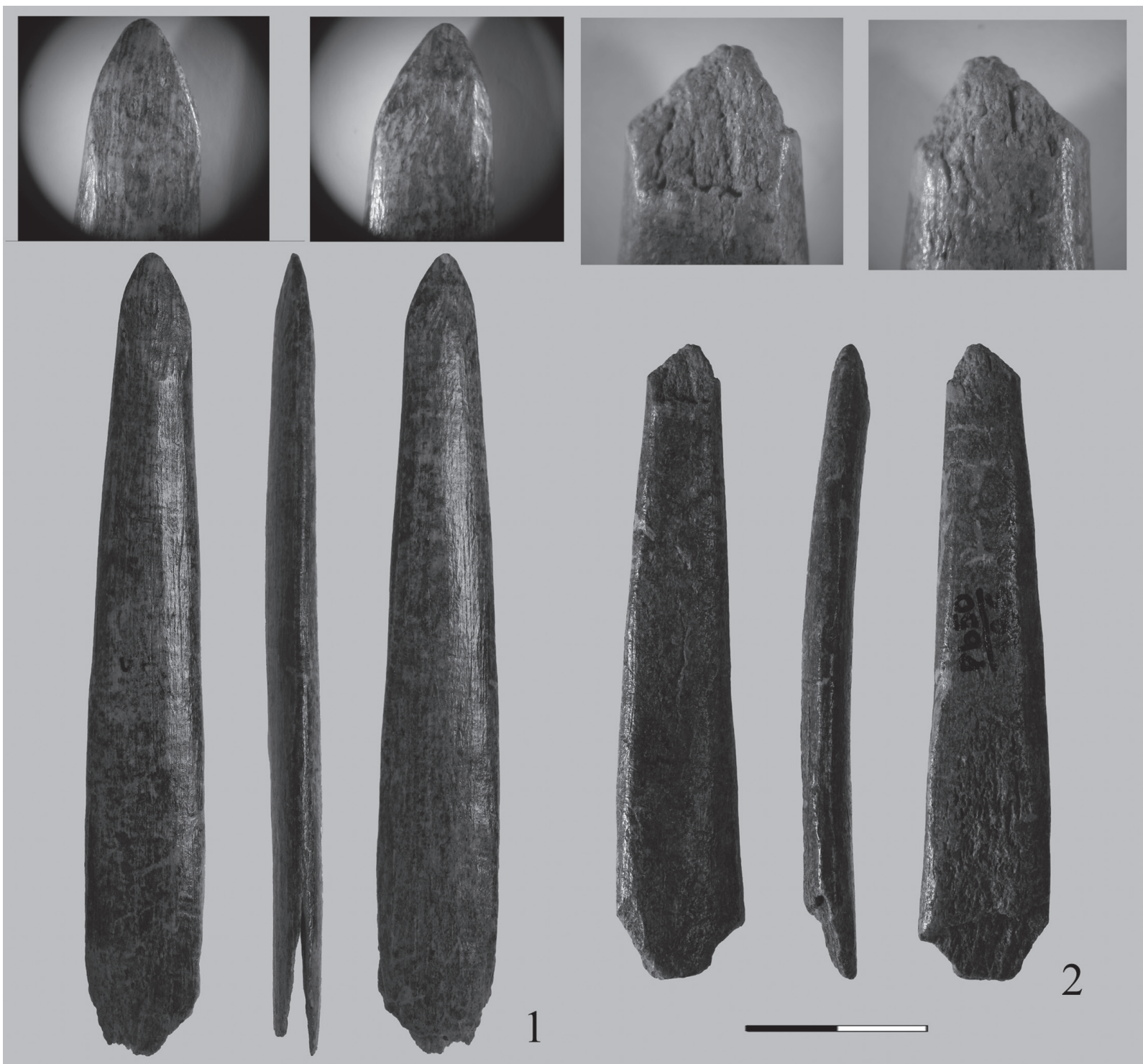

Fig.10. Split based point with rejuvaneted tip (1) and artefact with bifcial spin-off (2. photo: J. Kardos, Hungarian National Museum)

J. Hahn refers to this piece as an elongated ivory pendant, ${ }^{60}$ missing from the pieces listed by E. Álvarez Fernández and O. Jöris and from the review of M. Patou-Mathis and her colleagues ${ }^{61}$ In the former paper, however, imitations of atrophied deer canines were reported from the Aurignacian or Protoaurignacian of Gatzarria of antler, from Les Rois and Blanchard I of bone ${ }^{62}$ and stratum $\mathrm{G}$ of the Mochi Rockshelter of steatite and bone. ${ }^{63}$ In my view the Istállóskő specimen is most probably a roughly worked canine imitation of antler, unique piece among the Palaeolithic finds in Hungary.

${ }^{60}$ HAHN 1972, 1977 - With a reference to the paper of Hahn M. Vanhaeren and F. d'Errico mentioned an antler-imitation of a perforated red deer canine and an elongated bead of ivory from the Istállóskő cave (VANHAEREN-D’ERRICO 2006).
${ }^{61}$ ÁlVAReZ FernánDEZ-JÖRIS 2008; PATOU-MATHIS et al. 2017.

\footnotetext{
62 ÁlvareZ FernÁNDEZ-JÖRIS 2008, 39.

${ }^{63}$ KUHN-STINER 1998, S186.
} 


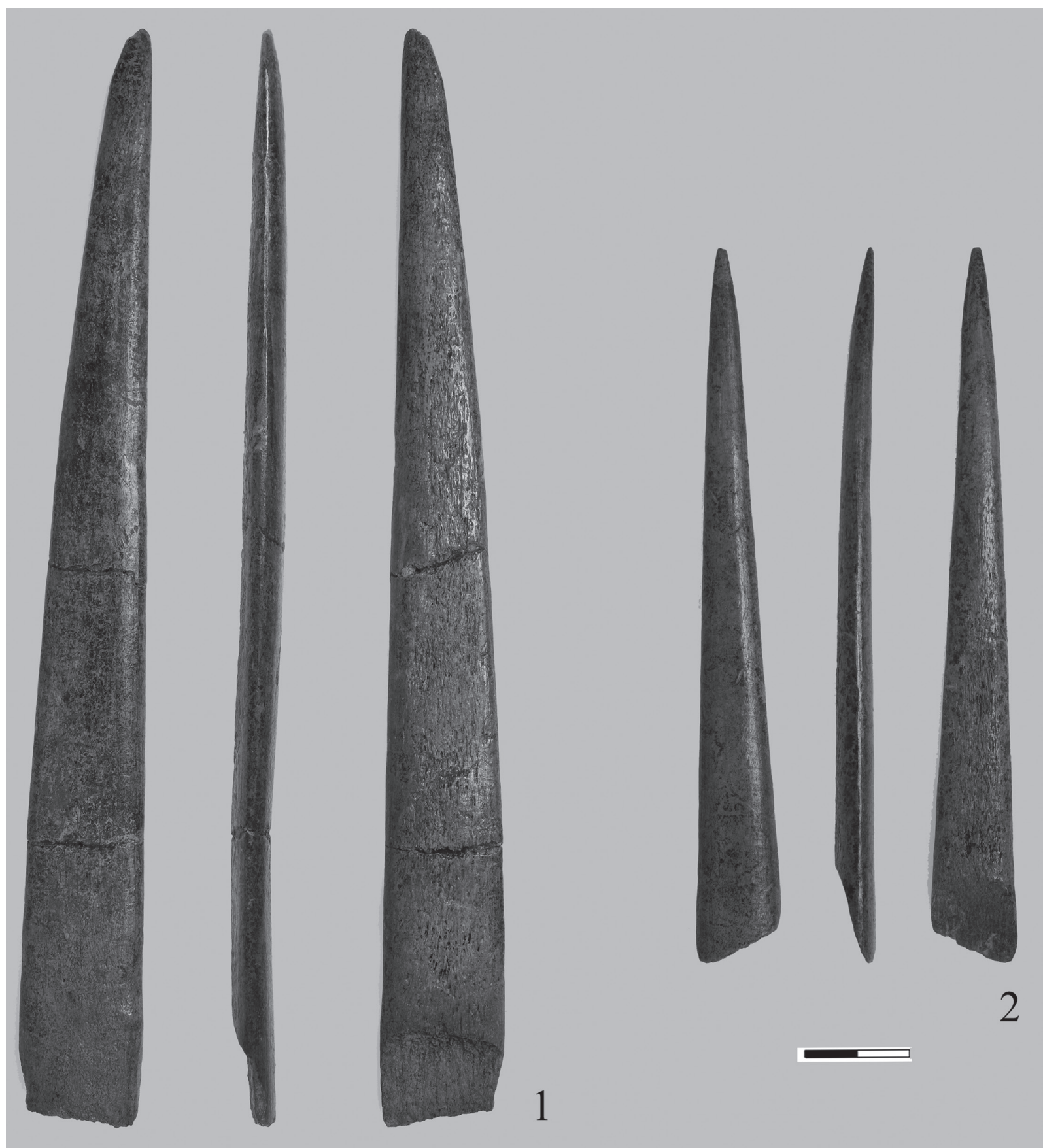

Fig. 11. Large bevelled points from the Istállóskő cave (photo: J. Kardos, Hungarian National Museum) 


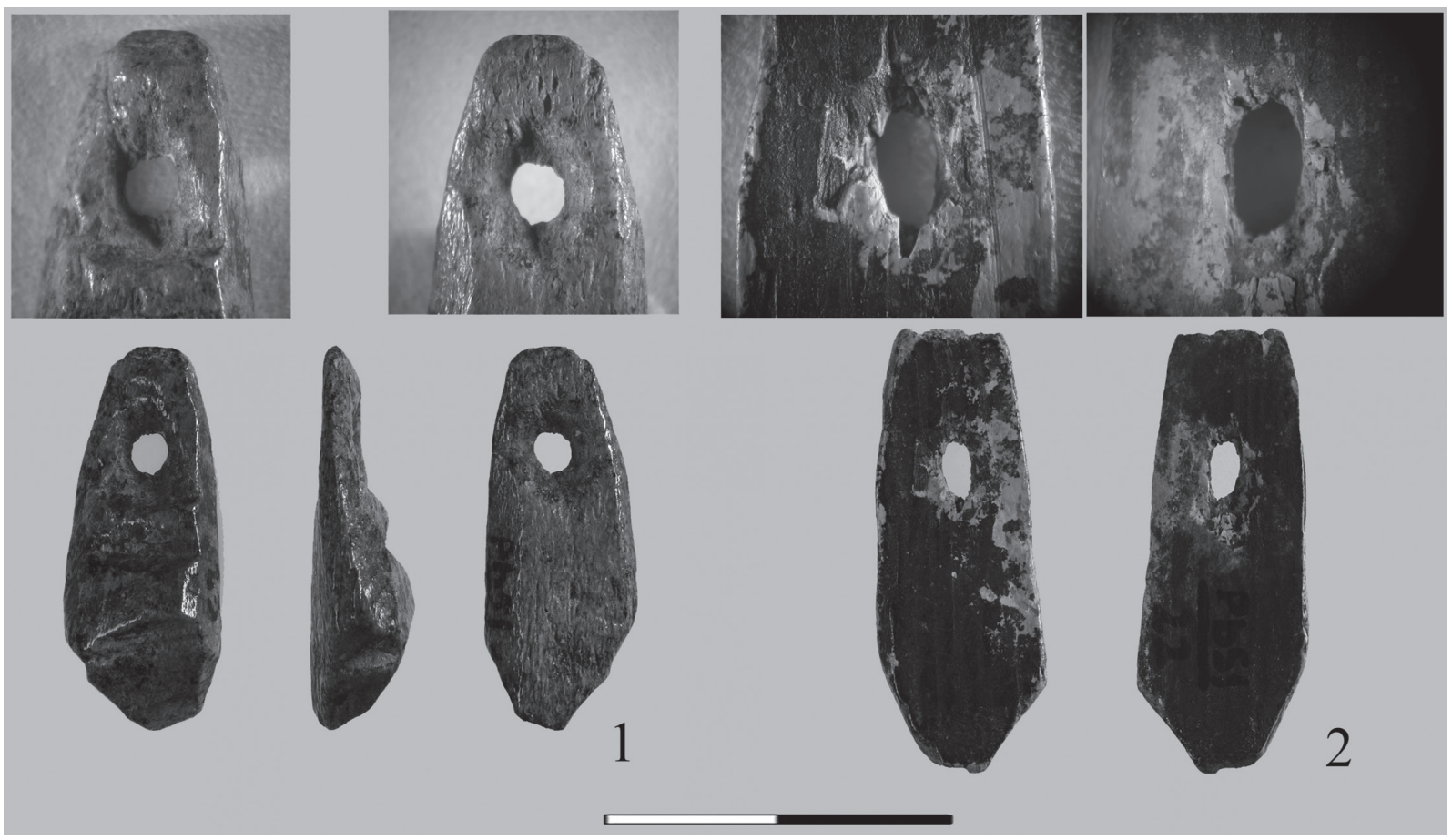

Fig. 12. Pendants of antler (1) and ivory from the Istálóskő cave (photo: J. Kardos, Hungarian National Museum)

\section{IVORY ARTEFACTS FROM THE LOWER LAYER OF THE ISTÁLLÓSKŐ CAVE}

The large number of the ivory artefacts from the lower layer of the Istállóskő cave can be misleading because of the fragmentary, platy structure of the raw material and the unwarranted activities at the opened excavation blocks. ${ }^{64}$

The scarce data on the spatial distribution of ivory artefacts suggest that the highest concentration were found in trench III and VI where numerous fragments were collected also in 1950. On the other hand, in the next year a single pendant was found.

Ten pieces are classified as rods (baguette), i.e. pieces with traces of the cursory manufacture, covered partly with the original surface of the tusk (Fig. 13). In some cases longitudinally running parallel incisions are visible on these pieces. In the collection there are three certainly not naturally fragmented pieces ('flakes' preformed by the structure of the tusk) which could be conjoined to one of the rods. Beside the numerous ivory fragments, partly of natural origin and similar to the "Veldenian" tools of the older literature, there is only a single well shaped piece of circular cross section which belongs to the rather neutral category of 'stick' (Fig. 14).

Finally, a pendant of pentagonal shape was found during the excavations of trench VIII (Fig. 12.2). The blank with plano-convex cross section used for manufacturing of this piece was similar to the flakes removed from the rods, preserved in a very fragmentary state. One of the edges of the pendant seems to be intact, well-preserved and not covered by dark coating and showing the original edge of the flake. The other edge is fragmented the flake is truncated and seemingly re-shaped. The convex surface of the pendant was manufactured by longitudinal scraping. The oval-shaped perforation shows traces of intense use, i.e. suspension.

\footnotetext{
${ }^{64}$ See above, fn 31
} 


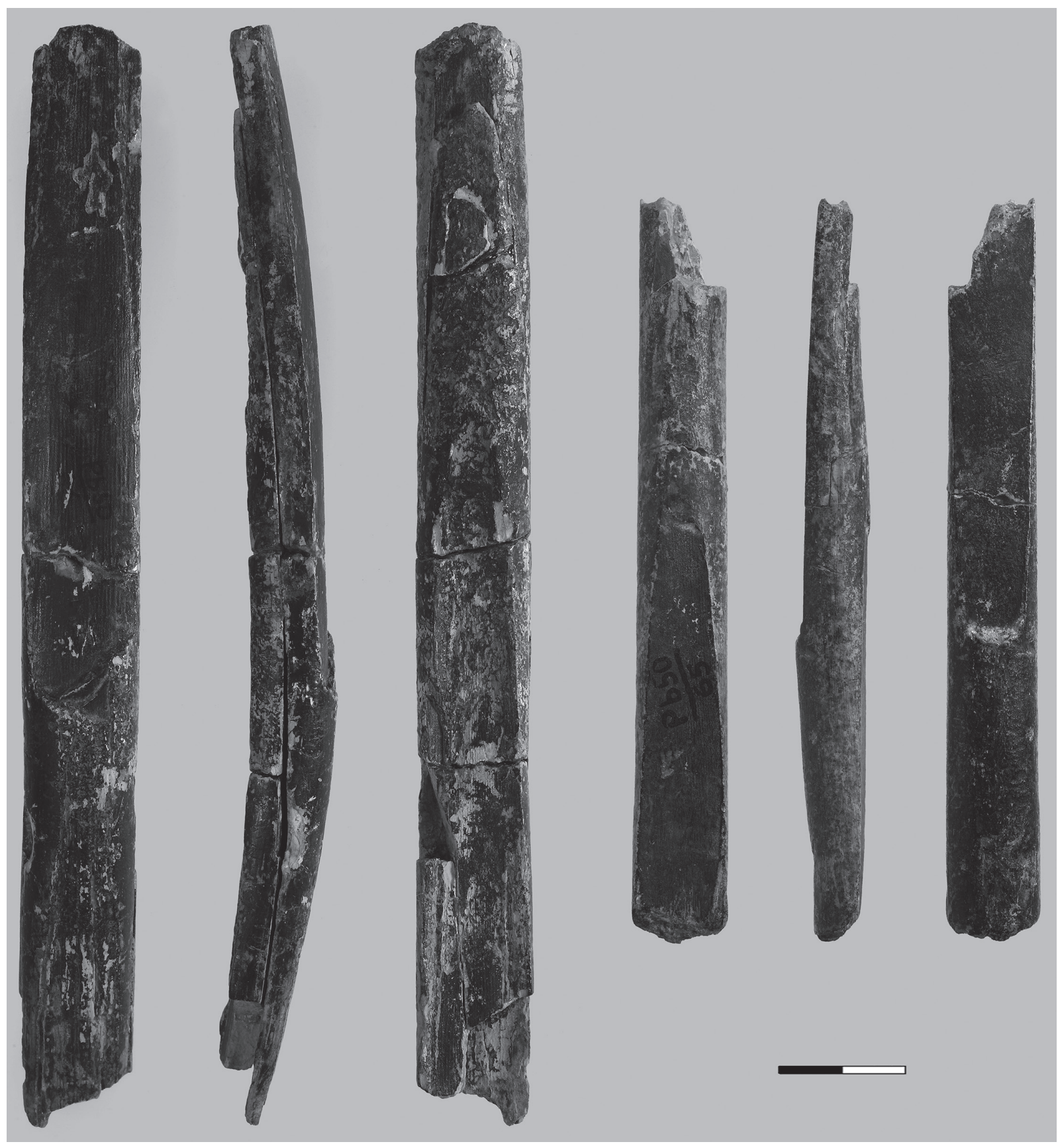

Fig. 13. Ivory rods from the Istállóskő cave (photo: J. Kardos, Hungarian National Museum) 


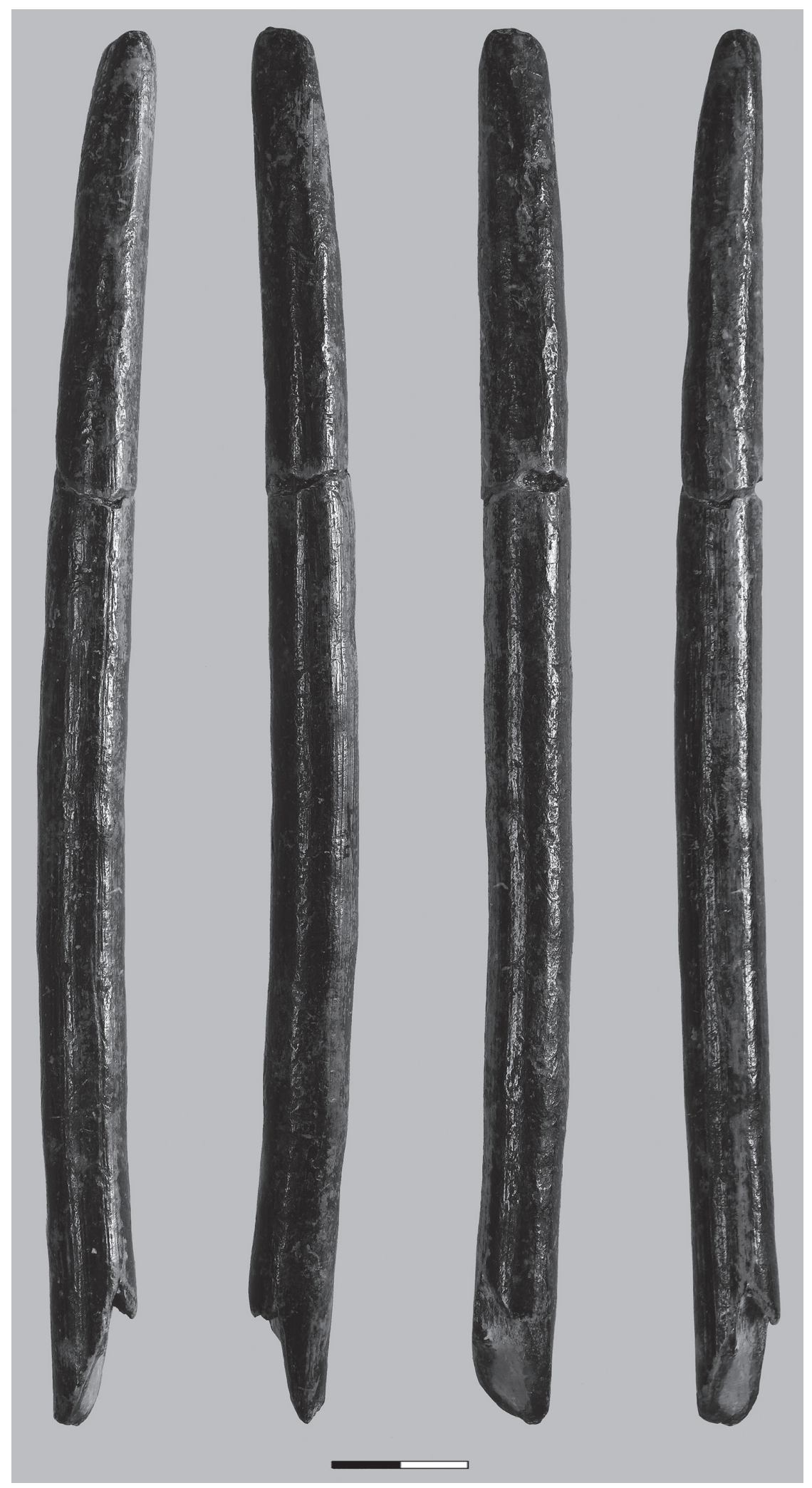

Fig. 14. Finely elaboretad stick from trench III (photo: J. Kardos, Hungarian National Museum) 




Fig. 15. Split based point from the upper layer (1) and from the excavations before 1914 (2) of the Istállóskő cave (photo: J. Kardos, Hungarian National Museum)

\section{DISCUSSION AND CONCLUSIONS}

Based on the analysis of the lithic and osseous artefacts excavated in the lower layer of the Istállóskő cave the site is interpreted as a hunting stand ${ }^{65}$ in a cave bear den, hidden at the end of a long, narrow and deep valley at a relative height of $80 \mathrm{~m}$. The manganese oxide precipitates in stream deposit and the formation of hydroxyl-apatite is linked the presence of bat guano ${ }^{66}$ both suggesting episode-like occupations in the cave, when the tools were rejuvenated and discarded and there are very few traces of on-site tool production. The rather coarse data reflects the episode-like human occupations, as similar to the distribution of lithic tools ${ }^{67}$ two concentrations lying at the northern and the southern wall of the cave were observed.

The absence of waste material, the presence of single blanks and rough-outs, together with the taphonomic problems of the osseous artefacts make problematic the technological analysis ${ }^{68}$ of one of the richest collections of antler tools in Central Europe. In my view, the Istállóskő assemblages clearly show the limitations of the technological approach, which is rather regrettable as on the open-air sites of this peculiar period few if any osseous arte-

\footnotetext{
${ }^{65}$ This way the 45 years old observations by G. ALBRECHT and his colleagues (1972) and J. HAHN (1977, 171) were verified, c.f.

${ }^{66}$ WHITE et al. 2009; ONAC 1996.

${ }^{67}$ MARKó 2015, 20. Patou-Mathis et al. 2017, 78

${ }^{68}$ Cf. Tejero-Grimaldi 2015, 61.
} 
facts were found. On the other hand, at least three diagnostic fracture types were identified on the tools and various ways of scraping for the point rejuvenation.

At the ivory pieces a hypothetical operational chain could be reconstructed, as the flakes of triangular or pentagonal shape and plano-convex cross-section were removed from the rods (similar to the observations on the Jankovich assemblage $\left.{ }^{69}\right)$ and could have been transformed to pendant. However, the fragmentary nature of the assemblage does not allow us to draw any general conclusion. In the future the study of the pieces (identified as 'knives') excavated in the nearby Peskö cave may shed some light on the question of ivory manufacturing in the Early Upper Palaeolithic period.

The osseous tools of the lower layer of the Istállóskő cave are represented by split based points, large bevelled pieces, flat points similar to the Mokrica types, accompanied by two pendants and an ivory stick. The chisels and awls on the other hand should be deleted from the type list of the Istállóskő assemblage.

Split based points are generally regarded as type fossils of the Aurignacian I industry, ${ }^{70}$ however, in SouthEast Europe these artefacts are associated with a rather uncharacteristic lithic industry or by bifacially worked leaf shaped implements or by Middle Palaeolithic tools types. ${ }^{71}$ This way the dichotomy, the co-occurrence of the Aurignacian-type osseous industry and the not-Aurignacian lithic tools was verified by the present study.

According to our incomplete data the site formation was a complex process. The elements of refit groups IV and VII may illustrate certain horizontal ${ }^{72}$ and vertical moving of the artefacts. This later case, documenting the direct connections between the lower and the upper artefact bearing layers is not unique among the cave localities in south-eastern Europe, e.g. the fragments of a massive-base (Mladeč-type) point were found in level $\mathrm{h}$ and $\mathrm{i}$ in the Velika Pećina cave ${ }^{73}$ and the fragments of a split based point found in the Early Aurignacian layer F and the ProtoAurignacian layer $\mathrm{G}$ of Riparo Mochi were also conjoined. ${ }^{74}$

Interestingly, in the Istállóskő cave a typical split based point (Fig. 15.1) was found in the upper layer, and even if the details of the recovery are not known, according to the excavator, the piece was found clearly in a secondary position. ${ }^{75}$ Furthermore, during the early excavations of the Istállóskő cave (1912-1948) relatively few osseous artefacts were collected and the pieces enumerated by M. Gábori are partly missing from the collections today. ${ }^{76}$ Ironically a split based point (Fig. 15.2) published in the same paper as an artefact from the Peskö cave, ${ }^{77}$ was in fact found during the excavations of the Istállóskő cave before 1914, as in the hand-written list of artefacts of the inventoried items of 167/914 of the Hungarian National Museum ${ }^{78}$ is clearly indicated. ${ }^{79}$ As during these early excavations a single artefact bearing layer, the later upper/Aurignacian II layer was found ${ }^{80}$ this antler tool should have been excavated in the same assemblage, too. Beside the possible role of the taphonomical processes and the problems with the field observations and documentations, typical for the old excavated assemblages, there is another possible explanation for the late occurrence of the split based point. As the tool found in the Divje babe cave (Slovenia) yielded a relatively young radiocarbon age ${ }^{81}$ possibly these artefacts are not necessarily linked to the early phase of the Aurignacian or contemporaneous entity. The chronological questions of these two points from the Istállóskő cave can be answered by direct age determinations.

Finally, the analysis on the Istállóskő osseous industry showed that taking into considerations all the available pieces, field documentations and published data, the old-excavated assemblages can answer several wellformed questions and even to raise new problems. However, the results of this study are only hypotheses which

${ }^{69}$ MARKó 2011, 100, Fig. 5

${ }^{70}$ E.g: DaVies 2001, 198; Liolios 2006; LuCAS 2006; TEYSSANDIER-LIOLIOS 2008, 741; ZILHÃO-D'ERRICO 2003, 343.

${ }^{71}$ For the details, see: MARKÓ 2013a, 196-198.

${ }^{72}$ C.f. Albarella 2016, 356 who argues that the 'movement' of bones (and artefacts) before the initial burial is interpreted after the behavioural pattern and not as taphonomic bias. In my view, the short and very short occupations of the Istállóskő cave rather suggest for natural agents (cave bears, flowing water, etc.) at the interpretation of the displacement of the fragmented pieces.

${ }^{73}$ Karavanić-SMith 1998, 239, Fig. 10.8.

${ }^{74}$ TEJeRO-GRIMALDI 2015, 63-65.

${ }^{75}$ VÉRTES 1955, 124, Taf. XLII:3, cf.: Dobosi 2002, 99

\footnotetext{
${ }^{76}$ GÁBORI 1951, 9, T. II:9-12: two bone rods, a point fragment and an artefact of antler(?).

${ }^{77}$ GÁBORI 1951, 10, T. III:2. - The more recent papers repeated this information, see: VÉRTES 1955, 262, fn 8; ALBRECHT et al. 1972, Taf. 13, nr. 253; HAHn 1977, 123, Taf. 148:5. - Earlier I had published this piece as found in an unknown locality: MARKó 2011, fn 101, Fig. 10:3.

${ }^{78}$ Stored in the Archives of the Hungarian National Museum under the number 23.Sz.I.

${ }^{79}$ In the same list several lithic artefacts published recently were also enumerated from the Istállóskő cave, see MARKó 2015, Fig. 5.1-2, cf. Hillebrand 1935, Taf. III:2; Kadić 1934, Fig. 31.

${ }^{80}$ For the details and references, see: MARKó 2015.

${ }^{81} 29,760 \pm 340$ B.P.: MoREAU et al. 2015, 169-170.
} 
should be checked by further field works using modern methods. New excavations, close to trench VIII of the 1951 season would be desirable. A pendant of rib was found in the upper layer and the lower unit yielded a split based point (Fig. 9.3) and the pendant of ivory (Fig. 12.2). ${ }^{82}$ Additionally, two bifacially worked tools were found very close to trench VIII, ${ }^{83}$ most probably in the lower artefact-bearing layer. Only further field works could shed light on the cultural and stratigraphic relations of the bifacial lithic tools and the osseous points.

\section{REFERENCES}

ADAMS 1998

ADAMS 2002

ADAMS 2007

ADAMS-RINGER 2004

Albarella 2016

AlbRECHT et al. 1972

ÁlVAREZ FERNÁNDEZ-JÖRIS 2008

BÁNESZ 1976

BERTOLA et al. 2013

BRODAR 1985

BRODAR-BRODAR 1983

DAVIES 2001

DoBosi 1975

Dobosi 2000

Dobosi 2002

GÁBORI 1951

GÁBORI 1964

GÁBORI 1969

HAHN 1969

HAHN 1972

HAHN 1977

HILLEBRAND 1935

JÁNOSSY 1955
= B. AdAms: The Middle to Upper Paleolithic Transition in Central Europe: The record from the Bükk Mountains region. BAR IntSer 693. Oxford 1998.

= B. ADAMS: New radiocarbon dates from Szeleta and Istálló-kő caves, Hungary. Praehistoria 3 (2002) 53-55.

= B. AdAms: Gulyás archaeology: The Szeletian and the Middle to Upper Palaeolithic transition in Hungary and Central Europe. In: New Approaches to the Study of Early Upper Palaeolithic 'Transitional' Industries in Western Eurasia. Transitions great and small. Eds: J. Riel-Salvatore, G. A. Clark. BAR IntSer 1620. Oxford 2007, 90-110.

= B. AdAms-Á. RingeR: New C14 dates for the Hungarian Early Upper Palaeolithic. CurrAnt 45 (2004) 541-551.

$=$ U. AlbarElla: Defining bone movement in archaeological stratigraphy: a plea for clarity. Archaeological and Anthropological Sciences 8 (2016) 353-358.

= G. Albrecht-J. HaHN-W. C. TORKE: Merkmalanalyse von Geschossspitzen des mittleren Jungpleistozäns in Mittel- und Osteuropa. Archaeologica Venatoria 2. Stuttgart 1972.

= E. Álvarez FERnÁndeZ-O. JÖRIS: Personal ornaments in the Early Upper Palaeolithic of western Eurasia: An evaluation of the records. Eurasian Prehistory 5/2 (2008) 31-44.

= L. BÁNESZ: Prírodné prostredie, hospodárska základňa a materiálna kultúra Aurignacienu strednej Európy - Natürliches Milieu, wirtschaftliche Basis und materielle Kultur des Aurignacien Mitteleuropas. S1A 24 (1976) 5-82.

= S. Bertola-A. Broglio-E. Christiani-M. De Stefani-F. Gurioli-F. Negrino-M. Romandini-M. VANHAEREN: La diffusione del primo Aurignaziano a sud dell'arco alpino. PreAlp 47 (2013) 123-152.

= M. BRodAR: Die Höhlen Potočka zijalka und Mokriška jama. Quartär 35/36 (1985) 69-80.

= S.BRODAR-M. BRODAR: Potočka zijalka, visokoalpskapostaja aurignacienskih lovcev - Potočka zijalka, eine hochalpine Aurignacjägerstation. Dela 1. Razreda SAZU 24. Ljubljana 1983.

= W. DAVIES: A very model of Modern Human Industry: new perspectives on the origin and spread of the Aurignacian in Europe. PPS 67 (2001) 195-217.

= V. T. DoBosi: Magyarország ős- és középsőkőkori lelőhely katasztere (Register of Palaeolithic and Mesolithic sites in Hungary). ArchÉrt 102 (1975) 64-76.

= V. T. Dobosi: Archaeological investigations at Bodrogkeresztúr-Henye. In: Bodrogkeresztúr-Henye (NE-Hungary) Upper Palaeolithic Site. Ed.: V. T. Dobosi. Budapest 2000, 5-111.

= V. T. Doвоsi: Bone finds from the Istállóskő Cave. Praehistoria 3 (2002) 79-102.

= M. GÁBORI: A paleolitikum csontipara Magyarországon - L'industrie de l'os du Paléolithique en Hongrie. ArchÉrt 73 (1951) 7-18.

= M. GÁBORI: A késői paleolitikum Magyarországon [The Late Palaeolithic Period in Hungary]. RégTan 3. Budapest 1964.

= M. GÁBORI: Regionale Verbreitung paläolithischer Kulturen Ungarns. ActaArchHung 21 (1969) $155-165$.

= J. HAHN: Gravettien-Freilandstationen im Rheinland: Mainz-Linsenberg, Koblenz-Metternich und Rhens. BonnerJb 169 (1969) 44-87.

= J. HAHN: Aurignacian signs, pendants and art objects in Central and Eastern Europe. WA 3 (1972) 252-266.

= J. HAHN: Aurignacien. Das ältere Jungpaläolithikum in Mittel- und Osteuropa. Köln-Wien 1977.

= J. Hillebrand: Magyarország őskőkora (Die ältere Steinzeit Ungarns). ArchHung 17. Budapest 1935.

= D. JÁNOSSY: Die Vogel- und Säugetierreste der spätpleistozänen Schichten der Höhle von Istállóskő. ActaArchHung 5 (1955) 149-181.
${ }^{83}$ In 1958 by L. Vértes and in 2000 by Á. Ringer and B. Adams: VérTes 1961; AdAMS 2002, 55; AdAMS-RINGER 2004, 548. - About the problems of stratigraphy, see: MARKó 2015, fn 111. 
KADIĆ 1934

KAMINSKÁ 2014

KARAVANIĆ 2016

KARAVANIĆ-SMITH 1998

KOLESNIK 2003

KoZŁowsKi et al. 2009

KRETZOI-VÉRTES 1965

KUHN-STINER 1998

Le Dosseur 2003

LIOLIOS 2006

MARKÓ 2011

MARKó 2013a

MARKÓ 2013b

MARKÓ 2015

Moreau et al. 2015

ONAC 1996

Patou-Mathis et al. 2017

POHAR 2004

PROŠEK 1953

RIGAUd 1972

SIMÁN 2006

SvobodA-Simán 1989

TARTAR 2003

TARTAR-WHITE 2013

TEJERo 2014
= O. KADIĆ: Der Mensch zur Eiszeit in Ungarn. A Magyar Királyi Földtani Intézet Évkönyve 30/1. Budapest 1934.

= L. KAMINSKÁ: Staré Slovensko. 2.: Paleolit a mezolit (Ancient Slovakia 2.: Palaeolithic and Mesolithic). Archaeologica Slovaca monographiae 2. Nitra 2014.

= I. KARAVANIć: Early Upper Paleolithic osseous points from Croatia. In: Osseous Projectile Weaponry. Towards an understanding of Pleistocene cultural variability. Ed.: M. C. Langley. Dordrecht 2016, 43-54.

= I. KARAVAnić-F. Smith: The Middle/Upper Palaeolithic interface and the relationship of Neanderthals and early modern humans in the Hrvatsko Zagorje, Croatia. JHE 34 (1998) 223-248.

= A. V. KolESNIK: Tafonomičeskaâ variabel'nost' pamâtnikov srednego paleolita Donbassa-Taphonomy variability of Donbass Middle Palaeolithic sites. In: Variabelnist' serednogo paleolitu Ukraini. Ed: L. Kulakovska. Kiiv 2003,106-115.

= J. K. KozŁowski-Zs. Mester-K. Zandler-A. BudeK-T. Kalicki-M. Moskal-Á. Ringer: Le Paléolithique moyen et supérieur de la Hongrie du nord: nouvelles investigation dans la région d'Eger. L'Anthropologie 113 (2009) 399-453.

= M. Kretzoi-L. Vértes: The role of vertebrate faunae and Palaeolithic industries of Hungary in Quaternary stratigraphy and chronology. ActaGeolHung 9 (1965) 125-144.

= S. L. KunN-M. C. Stiner: The earliest Aurignacian of Riparo Mochi (Liguria, Italy). CurrAnt 39 (1998) Supplement 1, 175-189.

= G. Le Dosseur: Sens et contre sens. Réflexions concernant l'orientation d'un geste technique observé sur des objets en matière osseuse du Levant. Préhistoires Méditerranéennes 12 (2003) 2-26.

= D. Liolios: Reflections on the role of bone tools in the definition of the early Aurignacian. In: Towards a Definition of the Aurignacian. Proceedings of the Symposium held in Lisbon, Portugal, June 25-30, 2002. Eds: O. Bar-Yosef, J. Zilhão. Trabalhos de arqueología 45. Lisboa 2006, 37-51.

= A. MARKó: A kései középső paleolitikum csontipara a Kárpát-medencében (The osseous industry of the Late Middle Palaeolithic period in the Carpathian Basin). ArchÉrt 136 (2011) 95-113.

= A. MARKó: Leaf-shaped lithic and osseous tools from old excavated cave sites: demonstrating associations. In: The Sound of Bones. Proceedings of the 8th Meeting of the ICAZ Worked Bone Research Group in Salzburg 2011. Archaeo-plus 5. Salzburg. Ed.: F. Lang, (2013) 191-202.

= A. MARKó: On the Middle Palaeolithic industry of the Jankovich cave (northeastern Transdanubia). ArchÉrt 138 (2013) 7-28.

= A. MARKó: Istállóskő revisited: lithic artefacts and assemblages, sixty years after. ActaArchHung 66 (2015) 6-38.

$=$ L. Moreau-B. Odar-T. Higham-A. Horvat-D. Pirkmajer-P. Turk: Reassessing the Aurignacian of Slovenia: Techno-economic behaviour and direct dating of osseous projectile points. JHE 78 (2015) 158-180.

= B. P. ONAC: Mineralogy of speleothems from caves in the Padurea Craiului Mountains (Romania), and their palaeoclimatic significance. Cave and Karst Science 23/3 (1996) 109-120.

= M. Patou-Mathis-C. Vercoutère-Gy. Lengyel-P. Szolyák-Zs. Mester: New interpretation of the Upper Palaeolithic human occupations at the Istállóskő cave (Bükk Mountains, Hungary). Eurasian Prehistory 13/1-2 (2017) 77-90.

= V. PoHAR: Stone- and bone artefacts from the excavations 1997-2000 in Potočka zijalka (Slovenia). In: Potočka zijalka. Palaeontological and Archaeological Results of the Campaigns 1997-2000. Eds: M. Pacher, V. Pohar, G. Rabeder. Mitteilungen der Kommission für Quartärforschung der Österreichischen Akademie der Wissenschaften 13 (2004) 211-216.

= Fr. ProšEK: Szeletian na Slovensku (Le Szeletien en Slovaquie). SlA 1 (1953) 133-194.

= A. Rigaud: La technologie du burin appliquée au matérial osseux de la Garenne (Indre). BSPF 69 (1972) 104-108.

= K. SimÁN: Tradition, laziness - curiosity, innovation. In: Stone Age - Mining Age. Eds.: G. Körlin, G. Weissgerber. Veröffentlichungen aus dem Deutschen Bergbau-Museum Bochum 148. Der Anschnitt Beiheft 19. Bochum 2006, 455-464.

$=$ J. Svoboda-K. SimÁn: The Middle-Upper Palaeolithic transition in Southeastern Central Europe (Czechoslovakia and Hungary). Journal of World Prehistory 3/3 (1989) 283-322.

= É. TARTAR: L'analyse techno-fonctionnelle de l'industrie en matière osseuse dite « peu élaborée ». L'exemple des pièces intermédiaires en os de l'Aurignacien ancien de la grotte des Hyènes (Brassempouy, Landes). Préhistoires Méditerranéennes 12 (2003) 139-146.

= É. TARTAR-R. WHITE: The manufacture of Aurignacian split-based points: an experimental challenge. JAS 40 (2013) 2723-2745.

= J-M. TEJERO: Towards complexity in osseous raw material exploitation by the first anatomically modern humans in Europe: Aurignacian antler working. JAA 36 (2014) 72-92. 
Tejero-Grimaldi 2015

TEJERo et al. 2012

TEysSANDIER 2006

TEYSSANDIER-LIOLIOS 2008

VANHAEREN-D'ERRICO 2006

VÉRTES 1955

VÉRTES 1956

VÉRTES 1961

VÉRTES 1965

VÖRÖS 1984

VÖRÖS 2000

VÖRÖs 2003-2004

WHITE et al. 2009

ZILHÃO-D'ERRICO 2003
= J-M. TEJERo-S. Grimaldi: Assessing bone and antler exploitation at Riparo Mochi (Balzi Rossi, Italy): Implications for the characterisation of the Aurignacian in South-western Europe. JAS 61 (2015) 59-77.

= J-M. Tejero-M. Christensen-P. Bodu: Red deer antler technology and early modern humans in Southeast Europe: An experimental study. JAS 39 (2012) 332-346.

$=$ N. TEYSSANDIER: Questioning the first Aurignacian: mono or multi cultural phenomenon during the formation of the Upper Palaeolithic in Central Europe and the Balkans. Anthropologie (Brno) 44/1 (2006) 9-29.

= N. TeysSANDiER-D. Liolios: Le concept d'Aurignacien: entre rupture préhistorique et obstacle épistémologique. BSPF 105 (2008) 737-747.

= M. VANHAEREN-F. D'ERRICO: Aurignacian ethno-linguistic geography of Europe revealed by personal ornaments. JAS 33 (2006) 1105-1128.

= L. VÉRTES: Neuere Ausgrabungen und paläolithische Funde in der Höhle von Istállóskő. ActaArchHung 5 (1955) 111-131.

= L. VÉRTES: Gruppen des Aurignacien in Ungarn. ArchA 19/20 (1956) 15-27.

= L. VÉRTES: Das Verhältnis des Aurignacien zum Szeletien in der Istállóskőer Höhle. Germania 39/3-4 (1961) 295-298.

= L. VÉRTES: Az őskőkor és az átmeneti kőkor emlékei Magyarországon [Records of the Palaeolithic and Mesolithic in Hungary]. A magyar régészet kézikönyve 1. Budapest 1965.

= I. VÖRÖS: Hunted mammals from the Aurignacian cave bear hunters' site in the Istállóskö cave. FolArch 35 (1984) 7-31.

I. VöRÖs: Macro-mammals on Hungarian Upper Pleistocene sites. In: Bodrogkeresztúr-Henye (NE-Hungary) Upper Palaeolithic Site. Ed.: V.T. Dobosi. Budapest 2000, 186-212.

= I. VÖRÖs: Stratigraphy and biostratigraphy of Istállóskö cave. Praehistoria 4-5 (2003-2004) 33-76.

= W. B. White-C. Vito-B. E. Scheetz: The mineralogy and trace element chemistry of black manganese oxide deposits from caves. Journal of Cave and Karst Studies 71/2 (2009) 136-143.

= J. ZILHÃO-F. D'ERRICO: The chronology of the Aurignacian and Transitional technocomplexes. Where do we stand? In: The Chronology of the Aurignacian and of the Transitional Technocomplexes: Dating, Stratigraphies, Cultural Implications. Proceedings of Symposium 6.1 of the XIVth Congress of the UISPP (University of Liège, Belgium, September 2-8, 2001). Eds: J. Zilhão, F. d'Errico. Trabalhos de Arqueologia 33. Lisboa 2003, 313-349. 